\title{
Credit Supply and Monetary Policy: Identifying the Bank Balance-Sheet Channel with Loan Applications ${ }^{\top}$
}

\author{
By Gabriel Jiménez, Steven Ongena, \\ José-Luis Peydró, and Jesús SAurina**
}

Do contractive monetary policy and adverse economic conditions reduce bank loan supply (Bernanke and Gertler 1989; Bernanke and Gertler 1995)? And does the reduction in credit availability depend on bank balance-sheet strength (Bernanke and Gertler 1987; Bernanke and Blinder 1988; Bernanke 2007)? That is, do agency costs of borrowing between banks and their financiers - proxied by bank capital- and liquidity-tototal assets ratios as in Holmstrom and Tirole (1997) and Diamond and Rajan (2011), for example - make lending significantly more problematic during periods of higher monetary policy rates or lower economic activity? Put differently, is a bank balance sheet channel operational, and, if so, how potent is it?

To convincingly answer these questions two major identification challenges need to be addressed. First, the supply of credit needs to be disentangled from its demand. Tighter monetary conditions and lower economic growth may reduce both loan supply and demand. Supply may contract because—as already indicated—agency costs of banks may increase, but demand may contemporaneously fall because firm net worth and expectations for investment are reduced, and the cost of financing is higher. ${ }^{11}$ In addition, firms affected more by monetary and economic conditions

\footnotetext{
* Jiménez: Banco de España, PO Box 28014, Alcalá 48, Madrid, Spain (e-mail: gabriel.jimenez@bde.es); Ongena: Tilburg University, PO Box 90153, NL 5000 LE Tilburg, The Netherlands (e-mail: steven.ongena@ tilburguniversity.nl); Peydró: Universitat Pompeu Fabra, Barcelona Graduate School of Economics, Ramon Trias Fargas 25, 08005-Barcelona (Spain), and European Central Bank (e-mail: jose.peydro@gmail.com); Saurina: Banco de España, PO Box 28014, Alcalá 48, Madrid, Spain (e-mail: jsaurina@bde.es). The paper circulated before under the title: "Credit Supply: Identifying Balance-Sheet Channels with Loan Applications and Granted Loans." We thank three anonymous referees, Ugo Albertazzi, Andrés Almazán, Lamont K. Black, Nicola Cettorelli, Cem Demiroglu, Andrew Ellul, Benjamin Friedman, Giorgo Gobbi, Todd A. Gormley, Jørn I. Halvorsen, Philipp Hartmann, Karolin Kirschenmann, Manfred Kremer, Olfa Maalaoui Chun, Marco Pagano, Huw Pill, Jörg Rocholl, David Romer, João Santos, Gregory F. Udell, Vikrant Vig, Charlotte Østergaard, participants at the American Economic Association Meetings (Denver), 2010 NBER Summer Institute Conference Monetary Economics Group, the Financial Intermediation Research Society Meetings (Florence), the Fourth Banca d'Italia-CEPR Conference on Money, Banking and Finance (Rome), the European Finance Association Meeting (Bergen and Frankfurt), the European Economic Association Meeting (Barcelona), the HKUST-CKIRoF Conference on Global Market Integration and Financial Crises (Hong Kong), the CREDIT Conference (Venice), the TEMAFIC Conference (Nice), the third Unicredit Conference (Rome), the Istituto Luigi Einaudi European Bank Competition Project Workshop (Rome), the Western Galilee College Conference on Banking after the Financial Crisis (Akko), and seminar participants at Bocconi University, ECARES, the European Central Bank, the European School for Management and Technology, IESE-ESADE, the Federal Reserve Bank of New York, the Kiel Institute for the World Economy, Koç University, Norges Bank, and the University of Zurich for valuable comments. The authors thank the Fondazione Istituto Luigi Einaudi for partly sponsoring this research. Ongena acknowledges the hospitality of the European Central Bank and the Swiss National Bank while writing this paper. Any views expressed are only those of the authors and should not be attributed to the Banco de España, the European Central Bank or the Eurosystem.

${ }^{\dagger}$ To view additional materials, visit the article page at http://dx.doi.org/10.1257/aer.102.5.2301.

${ }^{1}$ See Bernanke and Gertler (1995) and Bernanke, Gertler, and Gilchrist (1996). The external finance premium in lending depends inversely on the borrowers' net worth (see Freixas and Rochet 2008). When borrowers have little wealth at stake, the potential divergence of interests between the borrower and the suppliers of external funds is
} 
may borrow more from affected banks (Gertler and Gilchrist 1994). All this implies that any analysis based only on macro data (Bernanke and Blinder 1992) or banklevel data (Kashyap and Stein 2000) may suffer from an omitted-variables problem. Second, if country business cycle conditions completely determine short-term interest rate changes, which may be the case in many countries (e.g., through a Taylor 1993-rule), separating the effects of monetary conditions from those of economic activity is problematic.

Our main contribution to the literature consists in taking crucial steps in addressing both identification challenges. In particular, we analyze the effects of monetary conditions and economic activity on the granting of loans with individual loan application records depending on the strength of bank balance sheets measured by bank capital and liquidity ratios, controlling for time-varying observed and unobserved firm heterogeneity with firm-month fixed effects (i.e., there is a dummy for every firm-year:month combination). The data are from Spain, a country where most firms are bank dependent and where monetary policy has been fairly exogenous.

Unique features of the Credit Register of Spain (CIR), which is collected by the Banco de España acting in its capacity as bank supervisor, help us to attain identification. During the last nine years the CIR recorded all monthly information requests lodged by banks on borrowers. Because banks monthly receive information on all outstanding loans and defaults of their current borrowers from CIR, they file information requests only following loan applications from firms that are currently not borrowing from them. Because the CIR database also contains detailed monthly information on all, new and outstanding, loans (over 6,000 euros) to nonfinancial firms granted by all credit institutions operating in Spain since 1984, we can match the set of corresponding loan applications with the loan that is actually granted by a bank. The loans granted to noncurrent borrowers surely do not involve simply the renewal or evergreening of outstanding loans. Moreover, Banco de España has complete monthly bank balance-sheet information also collected in its role as bank supervisor and has access to key firm characteristics, including identity. We analyze 2,335,321 loan applications in total.

The unique features of the CIR allow us to address the two major identification challenges. First, to separate bank loan supply from demand we study loan applications and exploit theoretically motivated interactions between economic and monetary conditions on the one hand and bank balance-sheet strength variables on the other (Bernanke, Gertler, and Gilchrist 1996; Kashyap and Stein 2000). The definition of the bank capital- and liquidity-to-total assets ratios we employ closely follows the theoretical literature that attributes a prominent role to net worth in reducing the agency costs of borrowing (Holmstrom and Tirole 1997; Holmstrom and Tirole 1998; Bernanke, Gertler, and Gilchrist 1999; Gertler and Kiyotaki 2010),

\footnotetext{
larger, increasing agency costs. In equilibrium, lenders must be compensated. As borrower net worth is procyclical (because profits and asset prices are procyclical), the external finance premium is countercyclical, amplifying the changes in credit availability (Bernanke, Gertler, and Gilchrist 1999; Matsuyama 2007). In Holmstrom and Tirole (1997) the agency problems depend on the capital-to-total-assets ratio; in Bernanke, Gertler, and Gilchrist (1999) net worth is also associated with the liquidity of the assets. Since banks not only face agency problems with their borrowers, but banks themselves are also borrowing funds from their depositors and other financiers, bank net worth may determine their own agency costs of borrowing (Bernanke 2007; Gertler and Kiyotaki 2010). See also Stiglitz and Weiss (1981). Boivin, Kiley, and Mishkin (2010) review the recent literature.
} 
which sharpens the interpretation of the coefficients on their interactions with monetary and economic conditions.

To achieve identification we further focus on the set of loan applications made in the same month by the same borrower or for the same loan to different banks of varying balance-sheet strengths (by including in the specifications firm-month or alternatively loan fixed effects). Within this set of loan applications, for which the (observed and unobserved) quality of potential borrowers is constant as in the credit crunch definition by Bernanke and Lown (1991), we study how monetary and economic conditions affect the granting of loans depending on bank capital and liquidity. Moreover, we analyze whether firms that get rejected in their initial loan application can undo the resultant reduction in credit availability by successfully applying to other banks.

Second, to distinguish between the impact of monetary and economic conditions, we rely on the observation that monetary policy in Spain has been fairly exogenous during the sample period. Spain accounts for around 10 percent of the euro area output and as a peripheral country its business cycle did not converge with those of the core countries of the euro area (Giannone, Lenza, and Reichlin 2010).

Our study yields the following robust results: higher short-term interest rates or lower GDP growth reduce the probability that a loan application is granted. The negative effect of higher short-term interest rate on loan granting is statistically stronger for banks with low capital or liquidity, whereas the negative effect of lower GDP growth is statistically stronger for banks with low capital. ${ }^{2}$ The estimated effects are also economically relevant. A 100-basis point increase (decrease) in the interest rate (GDP growth) reduces loan granting by weak banks by 11 (5) percent more than by strong banks (i.e., a weak bank is in the tenth percentile in both bank capital and liquidity; a strong bank is in the ninetieth percentile).

All findings are robust to multiple controls, in particular to the inclusion of firmmonth or loan fixed effects, implying that within the set of applications made in the same month or for the same loan by the same firm to different banks, banks with weaker balance sheets grant fewer loan applications when short-term interest rate are higher or when GDP growth is lower. This is the first evidence-we think-that clearly identifies that, under tighter monetary or economic conditions, low bank capital or liquidity begets a credit crunch. Finally, we find that firms that get rejected in their initial loan application cannot undo the resultant reduction in credit availability by applying to other banks, especially in periods of tighter monetary and economic conditions.

Overall, our results suggest that the strength of bank balance sheets plays a statistically significant and economically relevant role in channeling changes in shortterm interest rates and economic growth to the availability of credit. The rest of the article proceeds as follows. Section I presents the hypotheses we test, the database

\footnotetext{
${ }^{2}$ Loan applications have been available only during the last nine years. Hence, we also analyze the impact of monetary and economic conditions on the intensive margin of lending by employing all granted business loans in Spain during the 1988:II-2008:IV period. We saturate the specifications—which we further leave unreported-with firm-quarter fixed effects to account for unobserved (and observed) time-varying firm heterogeneity, where 80 percent of the credit volume is from firms with multiple banking relationships. We similarly find that for the same firm borrowing from at least two different banks in the same quarter the amount borrowed from the weaker bank declines more when monetary or economic conditions are tighter.
} 
we analyze, and the empirical strategy we employ. Section II explains the variables in detail and presents and discusses the results. Section III concludes and discusses the policy implications.

\section{Hypotheses, Data, and Empirical Strategy}

\section{A. Hypotheses}

The theory modeling how monetary and economic conditions affect loan supply, which we briefly summarized in the Introduction, yields two key testable hypotheses:

(H1) Higher short-term interest rates or lower GDP growth contract credit availability. (H2) The negative impact of higher short-term interest rates or lower GDP growth on credit availability is stronger for banks with lower capital or liquidity.

We address the main identification challenge with monthly loan application data and an empirical strategy based on interactions of monetary and economic conditions with bank capital- and liquidity-to-total assets ratios and combinations of fixed effects, notably firm-month or loan fixed effects..$^{3}$ We first discuss the dataset and then the empirical strategy we employ.

\section{B. Data}

The Credit Register of the Banco de España (CIR) contains confidential information on virtually all business loans granted by all banks operating in Spain. In particular, we focus on applications for commercial and industrial (C\&I) loans (82 percent of total loans) by nonfinancial publicly limited and limited liability companies (that account for around 95 percent of all firms) to commercial banks, savings banks, and credit cooperatives (that account for more than 95 percent of the entire Spanish financial system). ${ }^{4}$ The CIR is almost comprehensive, as the reporting threshold for a loan is only 6,000 euros. Given that we consider only C\&I loans, this threshold is very low, which alleviates any concerns about unobserved changes in bank credit to small and medium-sized enterprises (which may be more influenced by changes in monetary policy and business cycle under the

\footnotetext{
${ }^{3}$ A large empirical literature has investigated the bank- and firm-balance sheet channels of monetary policy and the business cycle independently, with the analysis done at macro, bank, or the firm level. On the macro and on the bank side, see Bernanke and Blinder (1992); Jayaratne and Morgan (2000); Kashyap and Stein (2000); Kishan and Opiela (2000); Ashcraft (2006); and Black, Hancock, and Passmore (2009), among others. On the firm side, see Gertler and Gilchrist (1994) and Bernanke, Gertler, and Gilchrist (1996), for example. The literature accounted for loan demand through observed firm characteristics like industry or by interactions between economic/monetary conditions and bank/firm characteristics. There is also an empirical literature analyzing the balance sheet channels; see Gan (2007); Khwaja and Mian (2008); and Chaney, Sraer, and Thesmar (2009), among others. However, as far as we are aware, no paper so far has analyzed loan applications and included firm-month fixed effects to account for observed and unobserved time variation in firm loan demand and quality. As we argue in this section, loan applications and firm-time fixed effects are both necessary to identify the bank lending channel of monetary policy. Puri, Rocholl, and Steffen (2011) study loan applications from household loans, but do not use borrower fixed effects.

${ }^{4}$ Delgado, Salas, and Saurina (2007) explain the main features of the Spanish banking system, focusing on the differences in behavior of commercial banks, savings banks, and credit cooperatives. All of them compete under the same rules. See also Jiménez, Salas, and Saurina (2006).
} 
credit channel theory, for example).5 More than 350 banks and 130,000 firms are active in the CIR at any moment in time.

All banks in Spain automatically receive monthly updated information on the total current credit exposures and (possible) loan defaults — vis-à-vis all banks in Spain —of their own current borrowers. This information is extracted for the banks from the CIR. Any bank can also request this information on potential borrowers, which are defined as "any firm that seriously approaches the bank to obtain credit." The monetary cost of requesting this information is zero. But a law stipulates that a bank cannot ask for the information without consent by the potential borrower, indicating a seriousness of intent regarding the "financial relationship between bank and firm."

We observe all requests for information on potential borrowers after 2002:02 (before this date the requests were not stored). Though the requests can be made at any time, they are collated monthly and uniquely link borrowers with banks. Requests for information on firms that are currently borrowing from the requesting bank would yield information that is already known to this bank. Consequently, requesting information from the CIR is useful only if the firm has never before received a loan from the bank (that is requesting the information) or when the relationship between the firm and the bank ended before. In this way, the information requests focus on a key category of borrowers that do not simply renew or even evergreen existing loans at their current bank, but that seek new loans from another bank, i.e., the extensive margin of new lending. ${ }^{6}$

We analyze all requests lodged until 2008:12. Following the intensification of the crisis during the autumn of 2008 the European Central Bank took unprecedented action via both standard and nonstandard measures, altering the operation of the bank lending channel of monetary policy we wish to investigate. Nonetheless, in robustness we analyze our benchmark regression to an extension of the sample period to 2010:06.

For each request lodged between 2002:02 and 2008:12, we also observe whether the loan is accepted and granted, or not, by matching the loan application database with the CIR database, which contains the stock of all loans granted. Therefore, if multiple banks request information on a particular borrower within a three-month period, we can infer the bank that granted the loan and the banks that did not (results

\footnotetext{
${ }^{5}$ See, e.g., Gertler and Gilchrist (1993); Gertler and Gilchrist (1994); Bernanke and Gertler (1995); and Bernanke, Gertler, and Gilchrist (1996). The Credit Register contains more than 2,400,000 loans in the last month of 2008. The commercial and financial loans we study in this paper represent 82.6 percent of all loans that are granted (excluding leasing, factoring, and other specialized loans). Incomplete coverage of the widely used US (National) Survey of Small Business Finances or Loan Pricing Corporation datasets, for example, may complicate any analysis of bank lending.

${ }^{6}$ Since we cannot observe firm loan applications to their current banks, we also study firms that do not have any bank loan outstanding at the time of the loan application in robustness. These firms are noncurrent for all banks and hence we have the loan applications from all the banks. Credit needs and application propensity for this set of firms may also be more similar. Notice that approximately one fifth of the loans to borrowers entirely new to the bank are granted without any information request on record during the last sample quarter. This statistic shows that while the monetary cost of requesting the information is zero, nonpecuniary costs may not be. For example, an information request may slight borrowers (whose consent is required), involves waiting, uses management time processing the information, and/or may result in a loss of reputation vis-à-vis the Banco de España if prospects turn idle. Especially for the very good or connected borrowers that don't take a "check-and-wait" for an answer or during economic expansions when capacity constraints at the bank become binding, these nonpecuniary costs may be relevant. Banks may further not request information about the largest firms, for example, because these firms deal with many banks, are well-known, and/or do not seek regular loans. Our unreported empirical work on the intensive margin using all the actual loans granted to all firms addresses ensuing concerns on this account.
} 
are unaltered when we use two- and one-month matching periods). In case a bank requests information but does not grant the loan, either the bank denied the firm credit or the firm perceived the offered conditions by the bank to be less attractive than those of the loan it eventually took. Hence, we can link loan granting for the same firm within each month to bank balance-sheet strength.

We match the application dataset with bank and firm datasets, so that we have balance-sheet information for each bank that receives a loan application and/or grants a loan and for each firm that applies for a loan. The banks' dataset, at a monthly frequency starting in 1984, is owned by the Banco de España in its role as banking supervisor. The firms' dataset is available from the Spanish Mercantile Register at a yearly frequency and commences in 1992. We can match (to the firm-level data) 816,852 loan applications constituting the starting sample. ${ }^{7}$

\section{Empirical Strategy}

As we have the loan applications plus bank characteristics, in particular their capital and liquidity ratios as measures of their balance sheet strength, plus firm characteristics including identity, we are able to better disentangle the supply from the demand for loans. Through the loan applications, loan demand for each bank is in a sense given and observed, and each bank has to decide only on the granting of each loan- "its loan supply"-knowing the firm. As far as we are aware, ours is the first article that analyzes the impact of monetary and economic conditions on the probability loans are granted following applications from firms.

To analyze the bank lending channel we exploit the cross-sectional implications of the sensitivity of credit availability to monetary and economic conditions according to the strength of the bank balance sheets (see, e.g., Kashyap and Stein 2000). Following the theoretical literature we focus on bank net worth and liquidity. Because of lack of data, most other studies had to rely on size or debt as a proxy for net worth. Following Helmstrom and Tirole (1997) we define net worth as the capital-to-total assets ratio. ${ }^{8}$ Following Bernanke and Gertler (1995), Kashyap and Stein (2000), and Gertler and Kiyotaki (2010) we also feature a liquidity measure. As many banks actively deal with loan applications there is ample cross-sectional variation in both measures. To maximize variation in balance-sheet strengths across banks, we follow Kashyap and Stein (2000) and control for key time-varying bank characteristics (and only in robustness we include bank fixed effects).

Last but not least, to fully convincingly identify bank loan supply changes (as in the definition of Bernanke and Lown 1991) we focus on models that include either firm-month or loan fixed effects. Such models analyze the success of loan applications made by the same firm within the same month (or within three months for the same loan) to multiple banks that possibly differ in capital and liquidity. If monetary and economic conditions affect firm balance-sheet strength and/or loan demand (Bernanke and Gertler 1995), identification of loan supply requires controlling for

\footnotetext{
${ }^{7}$ When the firm characteristics are replaced in the specifications by the various sets of fixed effects, we commence again from the initial sample of 2,335,321 loan applications.

${ }^{8}$ Off-balance sheet volumes are very small in Spain. Hence, total bank assets cover most of the banks' businesses. Banks did not develop conduits or Structured Investment Vehicles (SIVs) because the prevailing accounting rules made banks consolidate these items and set aside sufficient capital.
} 
all observed and unobserved time-varying firm heterogeneity through either firmmonth or loan fixed effects. To analyze and quantify the total effect of monetary and economic conditions on loan granting, we can only include observable firm characteristics and firm fixed effects in the specifications, thereby inevitably weakening loan supply identification. Therefore, we report specifications with and without firm-month or loan fixed effects.

Finally, we investigate whether the loan supply restrictions we identified so far are binding and cannot be fully offset by firms turning to other banks. 9 Since firms may shift their applications between banks of different balance-sheet strengths, possibly neutralizing the supply effect measured with loan applications, we also study the success of future loan applications by firms that were either denied credit or, in general, the granting of any bank loans for firms that had applied to at least one bank.

Monetary policy in Spain has been fairly exogenous during the last 20 years, first when it was linked to the Bundesbank and then, as of January 1, 1999, within the Eurosystem (see Banco de España 1997 and Jiménez et al. 2008). Moreover, economic conditions in Germany (or the other core euro area countries) and Spain were only weakly correlated during the sample period. Consequently, there is a significant exogenous variation in monetary conditions, allowing us to disentangle its effects from those of local Spanish economic conditions.

Motivated by Bernanke and Gertler (1989); Bernanke, Gertler, and Gilchrist (1999); Ruckes (2004); and Dell'Ariccia and Marquez (2006), among others, and because of the presence in our sample of many small firms, we concurrently study the effect of both monetary and economic conditions on lending to firms. Though the current recession in Spain, for example, was partly initiated by the financial crisis abroad, providing a modicum of exogeneity to its start, in general, economic conditions are hardly exogenous to bank lending. But, for a given firm, economic conditions are fairly exogenous, and, in key specifications, all time-varying firm heterogeneity will be absorbed by firm-month fixed effects. Therefore, both to analyze the impact of economic conditions on loan granting and as a key control for monetary conditions (i.e., in a Taylorrule setting GDP growth determines short-term interest rates, for example), we also feature economic conditions in all benchmark regressions. In robustness we nevertheless also exclude it (and its interactions).

To analyze the bank lending channel, we use simple measures of monetary and economic conditions, i.e., the change in a short-term interest rate and GDP growth, which we detail and motivate further soon. To complete our specifications we include inflation, as an important economic determinant of short-term interest rates, and month, or firm-month, fixed effects that control for other macroeconomic factors.

\section{Dependent Variable, Independent Variables, and Results}

In this section we provide the main results of the article. We first define the main dependent variable, the independent variables, and the estimated specifications. Then we discuss the results.

\footnotetext{
${ }^{9}$ We analyze substitution of credit within the bank system given both the time frequency of the available data and the fact that Spain has a bank-dominated financial system and, therefore, bank loans constitute the majority of firm debt.
} 


\section{A. Main Dependent Variable: LOAN APPLICATION IS GRANTED}

Table 1 defines the dependent and independent variables employed in the first set of empirical specifications, as well as their descriptive statistics. The dependent variable we feature first is LOAN APPLICATION IS GRANTED (we recurrently shorthand this as "loan granting"), which equals one if the loan application by firm $i$ at time $t$ is approved by bank $b$ and the loan is granted in month $t$ to $t+3$, and equals zero otherwise (results are unaffected if the loan is granted in $t$ to $t+1$ or in $t$ to $t+2$ ). The average value of loan granting equals 42 percent (online Appendix A reports the number of loan applications and the loan granting probabilities simply by bank and firm capital ratio and total assets; some of the patterns that arise will be overturned in our analysis that controls for many more bank and firm characteristics and includes firm or firm-month fixed effects).

We match each loan application with its relevant bank and firm characteristics, in particular firm identity. The inclusion of firm (or firm-month) fixed effects in a logit (or probit) model naturally restricts the sample to those firms that filed at least one application that did result in a loan granted and one application that did not during the sample period (or in a month). To avoid this selection problem we employ linear probability models in the main regressions but study logit models in robustness. An additional advantage of employing linear probability models is that for the interaction terms, the main focus of the analysis, the estimated coefficients are directly interpretable and the standard errors require no corrections. 10

\section{B. Independent Variables}

As independent variables we include an array of macroeconomic conditions and bank/firm characteristics to control for changes in the quality and the propensity during the business cycle of different types of firms to apply for loans to a potentially varying set of banks that request information and approve the loans. The specifications do not include the characteristics of the loans that are granted, because these are the outcome of the application and granting process, but loan fixed effects that comprehensively account for loan-level quality heterogeneity are included later (online Appendix B provides summary statistics for all 346,884 loans granted; online Appendix $\mathrm{C}$ provides the mean loan characteristics by total firm assets).

Macroeconomic Conditions.-As macroeconomic conditions we include a shortterm interest rate measure of the annual changes in monetary policy conditions, annual GDP growth, and the annual inflation rate. According to Hypothesis 1 (H1) we expect the coefficient on the interest rate to be negative and the coefficient on GDP growth to be positive.

Our measure for the changes in monetary conditions, $\Delta I R$, is the change in the Spanish 3-month interbank interest rate during the last year. The average change in

\footnotetext{
${ }^{10}$ In nonlinear models the ordinarily reported standard errors and marginal effects of interacted variables require corrections (Ai and Norton 2003; Norton, Wang, and Ai 2004). For the benchmark specification we compare the standard errors of the linear probability model with the noncorrected and corrected standard errors of the logit model. In all cases the results are very similar.
} 
TABLE 1-Summary Statistics

\begin{tabular}{|c|c|c|c|c|c|c|c|}
\hline Variable & Units & Definition & Mean & SD & Min & Median & Max \\
\hline \multicolumn{8}{|l|}{ Dependent variable } \\
\hline $\begin{array}{l}\text { LOAN APPLICATION IS } \\
\text { GRANTED } D_{i b t}\end{array}$ & $0 / 1$ & $\begin{array}{l}=1 \text { if the loan application by a firm } \\
\text { is approved and the loan is granted } \\
\text { by a bank, }=0 \text { otherwise }\end{array}$ & 0.42 & 0.49 & 0 & 0 & 1 \\
\hline \multicolumn{8}{|l|}{ Independent variables } \\
\hline \multicolumn{8}{|l|}{ Macroeconomic conditions $(t)$} \\
\hline$\Delta I R_{t}$ & $\%$ & $\begin{array}{l}\text { Annual change of Spanish 3-month } \\
\text { interbank interest rates }\end{array}$ & 0.19 & 0.83 & -1.56 & 0.19 & 1.41 \\
\hline$\Delta G D P_{t}$ & $\%$ & $\begin{array}{l}\text { Annual change of Spanish gross } \\
\text { domestic product in real terms }\end{array}$ & 3.13 & 0.93 & -0.85 & 3.35 & 3.98 \\
\hline$\Delta C P I_{t}$ & $\%$ & $\begin{array}{l}\text { Annual change of Spanish } \\
\text { Consumer Price Index }\end{array}$ & 3.33 & 0.77 & 1.43 & 3.40 & 5.27 \\
\hline \multicolumn{8}{|l|}{ Bank characteristics (b) } \\
\hline BANK CAPITAL RATIO $O_{b t-1}$ & $\%$ & $\begin{array}{l}\text { The ratio of bank equity over total } \\
\text { assets of the bank }\end{array}$ & 5.37 & 2.07 & 0.00 & 4.82 & 63.15 \\
\hline BANK LIQUIDITY RATIO ${ }_{b t-1}$ & $\%$ & $\begin{array}{l}\text { The ratio of liquid assets (cash and } \\
\text { balance with central banks, and } \\
\text { loans and advances to governments } \\
\text { and credit institutions) held by the } \\
\text { bank over the total assets of the bank }\end{array}$ & 17.02 & 8.03 & 0.04 & 15.83 & 92.07 \\
\hline $\ln \left(\right.$ TOTAL ASSETS $\left._{b t-1}\right)$ & - & $\begin{array}{l}\text { The log of the total assets of the } \\
\text { bank }\end{array}$ & 17.39 & 1.47 & 9.57 & 17.61 & 19.90 \\
\hline TOTAL ASSETS & $\begin{array}{l}000,000.000 \\
\text { EUR }\end{array}$ & 0 The total assets of the bank & 78.00 & 87.60 & 0.01 & 44.20 & 437.00 \\
\hline$R O A_{b t-1}$ & $\%$ & $\begin{array}{l}\text { The total net income over assets of } \\
\text { the bank }\end{array}$ & 0.94 & 0.55 & -8.93 & 0.91 & 11.92 \\
\hline DOUBTFUL LOANS RATIO $O_{b t-1}$ & $\%$ & The doubtful loan ratio of the bank & 0.83 & 0.85 & 0.00 & 0.56 & 31.24 \\
\hline HERFINDAHL BY INDUSTR $Y_{b t-1}$ & $\%$ & $\begin{array}{l}\text { The Herfindahl-Hirschman index } \\
\text { of the bank's credit portfolio by } \\
\text { industry }\end{array}$ & 26.35 & 8.86 & 12.77 & 23.20 & 87.94 \\
\hline \multicolumn{8}{|l|}{ Firm characteristics $(i)$} \\
\hline FIRM CAPITAL RATIO ${ }_{i t-1}$ & $\%$ & $\begin{array}{l}\text { The ratio of own funds over total } \\
\text { assets of the firm }\end{array}$ & 24.52 & 20.73 & 0.00 & 18.67 & 100 \\
\hline FIRM LIQUIDITY RATIO ${ }_{i t-1}$ & $\%$ & $\begin{array}{l}\text { The ratio of current assets over total } \\
\text { assets of the firm }\end{array}$ & 41.14 & 26.91 & 0.00 & 38.26 & 100 \\
\hline TOTAL ASSETS $_{i t-1}$ & $\begin{array}{l}000.000 \\
\text { EUR }\end{array}$ & The total assets of the firm & 6.98 & 75.95 & 0.00 & 1.32 & $27,200.00$ \\
\hline $\ln \left(\right.$ TOTAL ASSETS it $\left.-1_{1}\right)$ & - & The log of the total assets of the firm & 7.26 & 1.62 & 0.86 & 7.19 & 17.12 \\
\hline$A G E_{i t-1}$ & years & The age of the firm & 10.30 & 9.25 & 0 & 8 & 132 \\
\hline $\ln \left(1+\mathrm{AGE}_{i t-1}\right)$ & - & $\begin{array}{l}\text { The log of one plus the age of the } \\
\text { firm }\end{array}$ & 2.10 & 0.86 & 0.00 & 2.20 & 4.89 \\
\hline$R O A_{i t-1}$ & $\%$ & The return on assets of the firm & 6.46 & 9.74 & -36.07 & 4.89 & 63.16 \\
\hline $\begin{array}{l}\text { I(DOUBTFUL LOANS AT THE } \\
\left.\text { TIME OF THE REQUEST }{ }_{i t-1}\right)\end{array}$ & $0 / 1$ & $\begin{array}{l}=1 \text { if the firm had doubtful loans } \\
\text { the month before the loan was } \\
\text { requested, }=0 \text { otherwise }\end{array}$ & 0.01 & 0.09 & 0 & 0 & 1 \\
\hline $\begin{array}{l}\text { I(DOUBTFUL LOANS BEFORE } \\
\text { THE TIME OF THE } \\
\text { REQUEST } \\
\text { it-1 }\end{array}$ & $0 / 1$ & $\begin{array}{l}=1 \text { if the firm had doubtful loans } \\
\text { before the previous month to the } \\
\text { loan request, }=0 \text { otherwise }\end{array}$ & 0.09 & 0.29 & 0 & 0 & 1 \\
\hline $\begin{array}{l}\text { NUMBER OF MONTHS WITH } \\
\text { THE BANK } \\
\text { ibt-1 }\end{array}$ & months & $\begin{array}{l}\text { The duration of the relationship } \\
\text { between firm and bank }\end{array}$ & 7.84 & 23.48 & 0 & 0 & 278 \\
\hline $\begin{array}{l}\ln (1+\text { NUMBER OF MONTHS } \\
\left.\quad \text { WITH THE BANK }_{\text {ibt }-1}\right)\end{array}$ & - & $\begin{array}{l}\text { The log of one plus the duration of } \\
\text { the relationship between firm and } \\
\text { bank }\end{array}$ & 0.63 & 1.36 & 0 & 0 & 5.63 \\
\hline $\begin{array}{l}\text { NUMBER OF BANK } \\
\quad \text { RELATIONSHIPS }_{i b t-1}\end{array}$ & - & $\begin{array}{l}\text { The number of banks the firm is } \\
\text { currently borrowing from }\end{array}$ & 3.90 & 3.66 & 0 & 3 & 102 \\
\hline $\begin{array}{l}\ln (1+\text { NUMBER OF BANK } \\
\left.\text { RELATIONSHIPS } S_{i b t-1}\right)\end{array}$ & - & $\begin{array}{l}\text { The log of the number of bank } \\
\text { relationships of the firm }\end{array}$ & 1.35 & 0.65 & 0 & 1.39 & 4.63 \\
\hline \multicolumn{8}{|l|}{ Industry characteristic $(s)$} \\
\hline $\begin{array}{l}\text { INDUSTRY DOUBTFUL LOANS } \\
\quad \text { RATIO }_{s t-1}\end{array}$ & $\%$ & $\begin{array}{l}\text { The doubtful loan ratio of the } \\
\text { industry in which the firm operates }\end{array}$ & 0.91 & 0.60 & 0.06 & 0.73 & 4.91 \\
\hline \multicolumn{8}{|l|}{ Province characteristic $(p)$} \\
\hline NUMBER OF BANKS & - & $\begin{array}{l}\text { The number of banks in the province } \\
\text { where the firm is located }\end{array}$ & 116.52 & 32.52 & 11 & 111 & 179 \\
\hline $\ln \left(N U M B E R\right.$ OF BANKS $\left.S_{p t-1}\right)$ & - & $\begin{array}{l}\text { The log of the number of banks } \\
\text { in the province where the firm is } \\
\text { located }\end{array}$ & 4.72 & 0.29 & 2.40 & 4.71 & 5.19 \\
\hline
\end{tabular}

Notes: The number of observations equals $816,852 . t: 1$ to $83, b: 1$ to $184, i: 1$ to $267,618, s: 1$ to 10 , and $p: 1$ to 52 . EUR $=2008$ euros. 
the three-month interest rate during the sample period was 0.23 percent, ranging between -1.56 and 1.41 percent. The use of variations in the short-term interest rate as a measure that proxies the change in the stance of monetary policy is fully in line with the literature analyzing the credit channel at the micro level. ${ }^{11}$ Our main results are unaffected if we employ the level rather than the change in this interest rate. The use of a three-month interest rate is in line with many articles in Angeloni, Kashyap, and Mojon (2003), for example, that also use European data. Using the change in the overnight interbank interest rate yields very similar results, not surprisingly, as the correlation between the two series equals 0.95 .

GDP growth, $\triangle G D P$, is available only quarterly, while both the interest rate changes and the inflation rate are measured monthly. Hence, to be consistent with the frequency of loan applications and the other macroeconomic measures, we interpolate GDP growth for all intermediary months (results are unaffected if we do not interpolate). Thus defined, GDP growth averages 3.14 percent and varies between -0.85 and 3.98 percent. Finally, the average inflation rate, $\triangle C P I$, during the sample period was 3.33 percent, with the minimum and maximum at 1.43 and 5.27 respectively.

Bank Characteristics.-The summary statistics of Table 1 are based on the observations used in the first three regressions (that include only firm fixed effects). Bank balance-sheet data is taken at the end of the previous month $(t-1)$ and bank performance information over the previous month. We employ lagged values as monetary and economic conditions may determine the capital and liquidity ratios banks optimally choose.

The key bank balance-sheet variables we are interested in the bank's CAPITAL RATIO as a measure of the bank's net worth and the LIQUIDITY RATIO as a measure of its liquidity position (to distinguish them clearly from the corresponding firm ratios we add $B A N K$ in their label). The capital ratio is defined as the ratio of core capital over total assets of the bank (as in Bernanke and Lown 1991, for example). Core capital is defined as total equity plus retained earnings. As we use the book value of equity and assets are not risk adjusted, our measure is equivalent to a pure leverage ratio. Thus defined it has an average value of 5.4 percent. Unlike in the United States, there is no regulated minimum leverage ratio in Spain; hence, its minimum is very low (but results are not driven by this institutional difference as we show in robustness).

The LIQUIDITY RATIO is the ratio of liquid assets held by the bank (i.e., cash and deposits with central banks and other credit institutions, and public debt with a maturity up to one year) and the total assets of the bank. Banks on average held almost 17 percent of their balance sheet in liquid assets.

Lending behavior may vary across banks; hence, we control for bank variables that may affect bank lending (and in robustness also feature bank fixed effects). We therefore include: $\ln ($ TOTAL ASSETS), the log of the total assets of the bank (in 2008 euros); ROA, the return on assets of the bank; DOUBTFUL LOANS RATIO,

\footnotetext{
${ }^{11}$ See Jayaratne and Morgan (2000); Kishan and Opiela (2000); Ashcraft (2006); and Black, Hancock, and Passmore (2009), among others. Kashyap and Stein (2000) find very similar results using either the variation in the federal funds rate, the Boschen and Mills (1995) index, or the Bernanke and Mihov (1998) measure.
} 
the doubtful loan ratio of the bank; and the HERFINDAHL BY INDUSTRY, the Herfindahl-Hirschman index of the bank's credit portfolio by industry.

Firm Characteristics. - The composition of the pool of borrowers may change over time, and different firms may have different degrees of success in obtaining loans from banks. To control for these changes on the demand side, we include a broad set of firm characteristics and firm fixed effects. This set of effects controls for time-invariant unobserved firm heterogeneity. Later we introduce encompassing firm-month or loan fixed effects to account for all time-variant firm heterogeneity.

As firm-risk variables we feature: The CAPITAL RATIO, which is the ratio of own funds over total assets of the firm; the LIQUIDITY RATIO, the current assets over total assets of the firm; $\ln ($ TOTAL ASSETS), the log of the total assets of the firm (in 2008 euros $) ; \ln (1+A G E)$, the log of one plus the age of the firm in years; $R O A$, the return on assets of the firm; I(DOUBTFUL LOANS AT THE TIME OF THE $R E Q U E S T$ ), a dummy variable that equals one if the firm had doubtful loans the month before the loan was requested and equals zero otherwise; and IDOUBTFUL LOANS BEFORE THE TIME OF THE REQUEST), a dummy variable that equals one if the firm had doubtful loans any time previous to the month before the loan was requested and equals zero otherwise.

As firm-bank relationship variables we include: $\ln (1+$ NUMBER OF MONTHS WITH THE BANK), which is the log of one plus the number of months that the firm had a working relationship with the bank (i.e., had outstanding loans with the bank; though the firm currently does not borrow from the bank, as we are analyzing borrowing from new banks, the firm may have previously borrowed from the bank); and $\ln (1+$ NUMBER OF BANK RELATIONSHIPS $)$, the log of the number of bank relationships of the firm.

As an industry time-varying characteristic we include INDUSTRY DOUBTFUL LOANS RATIO, which is the doubtful loan ratio of the industry in which the firm operates to control for the probability of loan rejections over the business cycle in the industry of the firm. As a province time-varying characteristic, we include $\ln (N U M B E R$ OF BANKS), which is the log of the number of banks in the province where the firm is located (a province in Spain roughly corresponds to a Metropolitan Statistical Area in the United States), and which may capture the number of banks that a firm can approach and the intensity of local bank competition. ${ }^{12}$

\section{Specifications}

The specifications we estimate are at the loan application level, and we match the loan application outcomes (whether the loan is granted or not) with the associated macroeconomic, bank, firm, industry, and province information. That is, we control for-and exploit - the strength of the balance sheets of the banks associated with each loan application. Our empirical specifications assessing the

\footnotetext{
${ }^{12}$ All time-invariant firm characteristics, likely industry affiliation, location etc., are comprised by the firm fixed effects that are included in the specifications.
} 
probability a loan application is granted are broadly structured as follows (variable names are abridged):

$$
\text { LOAN GRANTED }{ }_{i b t}
$$

$$
\begin{aligned}
= & \beta_{I} \Delta I R_{t}+\beta_{G} \Delta G D P_{t}+\beta_{I C} \Delta I R_{t} \times C A P_{b t-1}+\beta_{I L} \Delta I R_{t} \times L I Q_{b t-1} \\
& +\beta_{G C} \Delta G D P_{t} \times C A P_{b t-1}+\beta_{G L} \Delta G D P_{t} \times L I Q_{b t-1}+\text { macro }_{t} \\
& + \text { bank }_{b t-1}+\text { firm }_{i t-1}+\text { other }_{t-1}+\varepsilon_{i b t} .
\end{aligned}
$$

The coefficients on the change in the short-term interest rate $(I R)$ and GDP growth $(G D P)$, and their interactions with bank capital $(C A P)$ and liquidity $(L I Q)$, comprise our two hypotheses. Hypothesis 1 is: $\beta_{I}<0$ and $\beta_{G}>0$. Hypothesis 2 is: $\beta_{I C}>0, \beta_{I L}>0, \beta_{G C}<0$, and $\beta_{G L}<0$. The sets of macro, bank, firm, and other variables will be replaced consecutively by appropriate combinations of fixed effects. In particular, we first feature firm fixed effects, then additively introduce both firm and month fixed effects, and, finally, introduce firm and month fixed effects multiplicatively (i.e., firm-month) or include loan fixed effects. ${ }^{13}$

\section{Results}

We first discuss the estimated impact of monetary and economic conditions $(\Delta I R$ and $\triangle G D P$ ) and, second, and more important, the estimated coefficients of the interactions between the economic and monetary conditions and the strength of the bank balance sheets_-proxied by BANK CAPITAL RATIO and BANK LIQUIDITY RATIO.

Economic and Monetary Conditions.-Table 2 reports for the baseline linear probability model the estimated coefficients, in a second column the standard errors that are clustered at the bank-month level, i.e., the level at which the interaction terms - which are the main focus of our analysis-vary (see Moulton 1986 for example), ${ }^{14}$ followed in a third column by the corresponding significance levels.

We start analyzing the direct effects of monetary and economic conditions on the probability that the LOAN APPLICATION IS GRANTED. In Model (1) of Table 2 we find that short-term interest rate hikes reduce loan granting, while GDP growth spurs loan granting (i.e., consistent with H1). A 100-basis point change in the interest rate or GDP (their standard deviations equal 83 and 92 basis points, respectively) changes the probability a loan application is granted by 1.4 and 4.7 percentage points, respectively. As the average probability of loan granting equals 42 percent, the estimated semielasticities equal 3.3 and 11.2 percent, respectively.

\footnotetext{
${ }^{13}$ In robustness, we further control for bank fixed effects and other variables.

${ }^{14} \triangle G D P$ is interpolated from a quarterly series; we alternatively aggregate and cluster at the bank-quarter level. We also multi-cluster errors simultaneously at the bank, firm, and month level (as in Cameron, Gelbach, and Miller 2011) and employ the procedure advocated by Petersen (2009). The key specifications from Table 2 are included in online Appendix E.
} 
Table 2-Regression Results, Loan Granting and Monetary Conditions (Dependent variable: LOAN APPLICATION IS GRANTED ${ }_{i b t}$ )

\begin{tabular}{|c|c|c|c|}
\hline Model & (1) & $(2)$ & (3) \\
\hline \multicolumn{4}{|l|}{ Macroeconomic controls $(t)$} \\
\hline$\Delta I R_{t}$ & $\begin{array}{c}-1.394 * * * \\
(0.254)\end{array}$ & $\begin{array}{l}-5.960 * * * \\
(0.625)\end{array}$ & \\
\hline$\triangle I R_{t} \times B A N K C A P I T A L R A T I O_{b t-1}$ & & $\begin{array}{l}33.384 * * * \\
(6.973)\end{array}$ & $\begin{array}{l}29.991 * * * \\
(6.979)\end{array}$ \\
\hline$\Delta I R_{t} \times B A N K L I Q U I D I T Y R A T I O O_{b t-1}$ & & $\begin{array}{l}15.396 * * * \\
(1.951)\end{array}$ & $\begin{array}{l}13.343 * * * \\
(2.044)\end{array}$ \\
\hline$\Delta G D P_{t}$ & $\begin{array}{l}4.734 * * * \\
(0.256)\end{array}$ & $\begin{array}{l}6.769 * * * \\
(0.552)\end{array}$ & \\
\hline$\Delta G D P_{t} \times B A N K C A P I T A L R A T I O_{b t-1}$ & & $\begin{array}{c}-28.580 * * * \\
(6.725)\end{array}$ & $\begin{array}{c}-28.728 * * * \\
(6.539)\end{array}$ \\
\hline$\Delta G D P_{t} \times B A N K L I Q U I D I T Y R A T I O_{b t-1}$ & & $\begin{array}{r}-3.340 \\
(2.433)\end{array}$ & $\begin{array}{c}-2.916 \\
(2.525)\end{array}$ \\
\hline$\Delta C P I_{t}$ & $\begin{array}{c}-0.081 \\
(0.183)\end{array}$ & $\begin{array}{c}-0.027 \\
(0.183)\end{array}$ & \\
\hline \multicolumn{4}{|l|}{ Bank characteristics $(b)$} \\
\hline BANK CAPITAL RATIO ${ }_{b t-1}$ & $\begin{array}{c}-0.671 * * * \\
(0.058)\end{array}$ & $\begin{array}{c}0.225 \\
(0.218)\end{array}$ & $\begin{array}{c}0.187 \\
(0.214)\end{array}$ \\
\hline BANK LIQUIDITY RATIO ${ }_{b t-1}$ & $\begin{array}{l}-0.069 * * * \\
(0.017)\end{array}$ & $\begin{array}{c}0.032 \\
(0.080)\end{array}$ & $\begin{array}{c}0.011 \\
(0.084)\end{array}$ \\
\hline $\ln \left(\right.$ TOTAL ASSETS $\left._{b t-1}\right)$ & $\begin{array}{c}0.001 \\
(0.001)\end{array}$ & $\begin{array}{c}0.001 \\
(0.001)\end{array}$ & $\begin{array}{c}0.001 \\
(0.001)\end{array}$ \\
\hline$R O A_{b t-1}$ & $\begin{array}{c}0.447 \\
(0.275)\end{array}$ & $\begin{array}{c}0.473 * \\
(0.267)\end{array}$ & $\begin{array}{l}0.758 * * * \\
(0.259)\end{array}$ \\
\hline DOUBTFUL LOANS RATIO ${ }_{b t-1}$ & $\begin{array}{l}0.307 * * \\
(0.154)\end{array}$ & $\begin{array}{l}0.355^{* *} \\
(0.151)\end{array}$ & $\begin{array}{c}0.237 \\
(0.146)\end{array}$ \\
\hline HERFINDAHL BY INDUSTRY $Y_{b t-1}$ & $\begin{array}{c}0.031 * \\
(0.016)\end{array}$ & $\begin{array}{l}0.057 * * * \\
(0.016)\end{array}$ & $\begin{array}{l}0.075 * * * \\
(0.016)\end{array}$ \\
\hline \multicolumn{4}{|l|}{ Firm characteristics $(i)$} \\
\hline FIRM CAPITAL RATIO ${ }_{i t-1}$ & $\begin{array}{c}0.015 * \\
(0.009)\end{array}$ & $\begin{array}{c}0.015^{*} \\
(0.009)\end{array}$ & $\begin{array}{l}0.019 * * \\
(0.009)\end{array}$ \\
\hline FIRM LIQUIDITY RATIO ${ }_{i t-1}$ & $\begin{array}{c}-0.003 \\
(0.005)\end{array}$ & $\begin{array}{c}-0.003 \\
(0.005)\end{array}$ & $\begin{array}{c}-0.003 \\
(0.005)\end{array}$ \\
\hline $\ln \left(\right.$ TOTAL ASSETS $\left._{i t-1}\right)$ & $\begin{array}{c}0.000 \\
(0.002)\end{array}$ & $\begin{array}{c}0.000 \\
(0.002)\end{array}$ & $\begin{array}{c}0.001 \\
(0.002)\end{array}$ \\
\hline $\ln \left(1+A G E_{i t-1}\right)$ & $\begin{array}{l}0.020 * * * \\
(0.005)\end{array}$ & $\begin{array}{l}0.018 * * * \\
(0.005)\end{array}$ & $\begin{array}{l}0.026 * * * \\
(0.004)\end{array}$ \\
\hline$R O A_{i t-1}$ & $\begin{array}{l}0.082 * * * \\
(0.010)\end{array}$ & $\begin{array}{l}0.083^{* * * *} \\
(0.010)\end{array}$ & $\begin{array}{l}0.083^{* * * *} \\
(0.010)\end{array}$ \\
\hline $\begin{array}{l}\text { I(DOUBTFUL LOANS AT THE TIME OF THE } \\
\quad \text { REQUEST } \\
\text { it-1 })\end{array}$ & $\begin{array}{l}-0.092 * * * \\
(0.009)\end{array}$ & $\begin{array}{l}-0.092 * * * \\
(0.009)\end{array}$ & $\begin{array}{l}-0.090^{* * * *} \\
(0.009)\end{array}$ \\
\hline $\begin{array}{l}\text { I(DOUBTFUL LOANS BEFORE THE TIME OF THE } \\
\quad \text { REQUEST } \\
\left.\text { REt-1 }_{1}\right)\end{array}$ & $\begin{array}{l}-0.037 * * * \\
(0.007)\end{array}$ & $\begin{array}{l}-0.037 * * * \\
(0.007)\end{array}$ & $\begin{array}{l}-0.033^{* * * *} \\
(0.007)\end{array}$ \\
\hline $\ln \left(1+N U M B E R\right.$ OF MONTHS WITH THE BANK $\left.K_{i b t-1}\right)$ & $\begin{array}{l}0.006 * * * \\
(0.001)\end{array}$ & $\begin{array}{l}0.007 * * * \\
(0.001)\end{array}$ & $\begin{array}{l}0.007 * * * \\
(0.001)\end{array}$ \\
\hline $\ln \left(1+N U M B E R\right.$ OF BANK RELATIONSHIPS $\left.S_{i b t-1}\right)$ & $\begin{array}{l}-0.162 * * * \\
(0.003)\end{array}$ & $\begin{array}{l}-0.162 * * * \\
(0.003)\end{array}$ & $\begin{array}{l}-0.161 * * * \\
(0.003)\end{array}$ \\
\hline \multicolumn{4}{|l|}{ Industry characteristic $(s)$} \\
\hline INDUSTRY DOUBTFUL LOANS RATIO ${ }_{s t-1}$ & $\begin{array}{c}-0.597 * * * \\
(0.193)\end{array}$ & $\begin{array}{c}-0.712 * * * \\
(0.192)\end{array}$ & $\begin{array}{c}-1.109 * * * \\
(0.180)\end{array}$ \\
\hline
\end{tabular}


Table 2-Regression Results, Loan Granting and Monetary Conditions (Dependent variable: LOAN APPLICATION IS GRANTED ibt $_{1}($ Continued $)$

\begin{tabular}{lccc}
\hline \hline Model & $(1)$ & $(2)$ & $(3)$ \\
\hline Province characteristic $(p)$ & & & \\
$\ln \left(\right.$ NUMBER OF BANKS $\left.S_{p t-1}\right)$ & $0.109 * * *$ & $0.110^{* * * *}$ & $0.107 * * *$ \\
& $(0.014)$ & $(0.014)$ & $(0.014)$ \\
Firm fixed effects & Yes & Yes & Yes \\
Month fixed effects & No & No & Yes \\
& & & \\
Observations & 816,852 & 816,852 & 816,852 \\
Number of bank-month clusters & 9,910 & 9,910 & 9,910 \\
Sample period & $2002: 02-$ & $2002: 02-$ & $2002: 02-$ \\
& $2008: 12$ & $2008: 12$ & $2008: 12$ \\
\hline
\end{tabular}

Notes: The table reports the estimated coefficients and robust standard errors (in parentheses) clustered at the bankmonth level from linear probability models estimated using least squares. Fixed effects are included ("yes") or not included ("no"). The set of month fixed effects includes a fixed effect for every (but one) year:month during the sample period. The variable definitions and summary statistics are in Table 1.

*** Significant at the 1 percent level.

** Significant at the 5 percent level.

* Significant at the 10 percent level.

But of course, the specification is still incomplete. Though a comprehensive set of observable firm characteristics and firm fixed effects is included, the specifications do not yet account for unobserved time-variant firm heterogeneity (i.e., changes over time in the quality in the pool of applicant firms that apply for and obtain loans from different banks) nor identify the effects of the changes in monetary and economic conditions on loan granting through the strength of the balance sheets of banks. Before tackling both issues, we discuss the coefficients on the bank and firm characteristics once and, then, turn back to the focus of our study.

Bank and Firm Characteristics. - The estimated coefficients on a number of bank and firm characteristics are across all specifications statistically significant, economically relevant, stable, and in line with straightforward priors. These results suggest, therefore, that these controls are at once needed and relevant.

More solvent and liquid banks are less prone to lend to new borrowers. Riskier banks (i.e., with higher NPL ratios and more industry concentrated loan portfolios) have a higher probability of granting loans to new borrowers. These results are further robust to the inclusion of firm-month or loan application fixed effects for example (unreported). Therefore, either using capital and liquidity ratios or other measures of bank strength, we find a negative sign. The introduction of interactions of bank capital and liquidity with the change in the interest rate or GDP growth rate reverses the signs on these variables.

The coefficient on firm capital and liquidity are only marginally or not significant, though capital becomes significant in models featuring interactions of bank capital and liquidity with economic and monetary conditions. Loan applications from older and more profitable firms, from firms with fewer doubtful loans at or prior to the loan application or from an industry with a lower doubtful loan ratio, and from firms with longer and fewer bank relationships located in a province with many banks may be more successful in applying. Hence, ceteris paribus more firms with a stronger balance sheet and with a longer and more impeccable track record can rely 
more on external financing (as in Jensen and Meckling 1976), and so can firms with stronger and bilateral relationships in competitive banking markets (see Freixas and Rochet 2008; and Degryse, Kim, and Ongena 2009 for reviews of theory and empirical evidence).

Overall, we find these estimated coefficients reasonable and their statistical significance and stability reassuring for our investigation of the different credit channels (as the working of these channels requires the imperfect substitutability between external and internal financing that is especially acute for small and opaque firms).

Bank Balance-Sheet Channel.-Model (2) analyzes the impact of monetary and economic conditions on loan granting through the bank balance-sheet channel. Model (2) therefore includes the interactions of the change in the short-term interest rate and GDP growth with bank capital and liquidity ratios suggested by Hypothesis $2(\mathrm{H} 2)$. As explained in the previous sections, interest rate changes and GDP growth are not highly correlated in Spain because of the relatively low level of synchronization of economic activity in Spain vis-à-vis the largest euro area countries, even after 1999 (Giannone, Lenza, and Reichlin 2010). This allows us to exploit simultaneously the variation in monetary conditions and output interacted with bank capital and liquidity.

The estimates in Model (2) suggest that the negative effect of positive changes in the short-term interest rate or lower GDP growth on the probability that a $L O A N$ APPLICATION IS GRANTED is stronger for banks with low capital or liquidity. To put it differently, "weaker" banks are more procyclical (in interest rate or GDP) in terms of loan granting than stronger ones. Hence, overall $\mathrm{H} 2$ is confirmed.

We now further explore the economic relevance of these estimated effects. We calculate the difference in semielasticities following changes in the short-term interest rate or GDP growth for banks with a low versus high capital or liquidity ratio (tenth versus ninetieth percentile, as in Kashyap and Stein 2000), i.e., at banks with a capital ratio of 3.5 versus 8.4 percent or a liquidity ratio of 7.7 versus 27.7 percent.

A 100-basis point increase in the interest rate decreases loan granting by lowly capitalized banks by 3.9 percent more than by highly capitalized banks, and by 7.3 percent more by lowly than by highly liquid banks. Therefore, weak banks (with both low capital and liquidity) on average decline loan granting by 11.4 percent more than strong banks. A 100-basis point decrease in GDP growth decreases loan granting by lowly capitalized banks by 3.4 percent more than by highly capitalized banks, and by 1.6 percent more by lowly than by highly liquid banks (the latter difference is not statistically significant, however). ${ }^{15}$ Hence, the change in the interest rate for the bank lending channel has a much larger differential impact in this case on loan granting than a similarly sized change in GDP growth (recall that their standard deviations were both close to 100 basis points), though the effect goes especially through bank liquidity.

\footnotetext{
${ }^{15}$ The calculations are: for the interest rate: $0.039=(0.01 \times 33.384 \times(0.035-0.084)) / 0.42$ and $0.073=(0.01$ $\times 15.396 \times(0.077-0.277)) / 0.42$; for GDP: $0.034=(-0.01 \times-28.580 \times(0.035-0.084)) / 0.42$ and 0.016 $=(-0.01 \times-3.340 \times(0.077-0.277)) / 0.42$.
} 
Our estimates capture the immediate impact on the probability of loan granting across all banks. ${ }^{16}$ The estimated effects are sizeable, yet the total impact on bank lending may be even larger if banks are slow to react to the changes in monetary or economic conditions, for example. The estimates strongly suggest that the bank balance-sheet channel of monetary policy is very potent.

Various Effects Models.-We now present the estimates of various fixed effects models. In Model (3) in Table 2 we add month fixed effects to the firm fixed effects. The set of month fixed effects includes a fixed effect for every (but one) year:month during the sample period. Month fixed effects capture the changes in economywide conditions, such as current and future expectations of GDP growth, inflation, and interest rates and general shocks affecting the economy. Hence, all variables at the country level are dropped from the empirical model, and the identification entirely comes from the interactions. Importantly, the estimated coefficients are similar to those in Model (2).

In Model (1) in Table 3, our benchmark regression, we replace the firm and month fixed effects by firm-month fixed effects. ${ }^{17}$ A firm-month fixed effects model accounts for the impact on loan granting of all observed time-varying firm characteristics (e.g., firm size and credit rating) and unobserved time-varying firm characteristics such as firm risk, quality, investment opportunities, the strength of the firm's bank relationships, and access to market finance (Petersen and Rajan 1994, among others). Including the set of all time dummies for each firm in the sample implies that all the independent firm characteristics (in addition to macro variables) have to be dropped from the model. In addition, to be included in the regression a firm must have filed more than one loan application within the same month, reducing in turn the number of observations from 816,852 to 328,891 (summary statistics are provided in online Appendix D). All estimated coefficients are similar to Models (2) and (3) in Table 2, and so is the resulting economic relevancy of these estimates. A 100-basis point increase in the interest rate decreases loan granting by lowly capitalized banks by 3.8 percent more than by highly capitalized banks, and by 6.2 percent more by lowly than by highly liquid banks. A 100-basis point decrease in GDP growth decreases loan granting by lowly capitalized banks by 3.4 percent more than by highly capitalized banks, and by 1.6 percent more by lowly than by highly liquid banks. ${ }^{18}$

In addition, in Model (2) in Table 3 we present estimates from a loan fixed effects model, where a firm must have filed multiple applications within the same month

\footnotetext{
${ }^{16}$ Kashyap and Stein (2000) find that four quarters following a 100-basis point hike in the federal funds rate the level of C\&I loans of the illiquid small bank will be between 0.6 and 5.3 percent lower than that of the liquid small bank. For large banks, there may be no or even a positive effect. The ratio of securities plus federal funds sold to total assets of the small banks ( $<95$ percent by asset size) varies between 21 and 60 percent (i.e., the tenth versus ninetieth percentile). See also Bernanke and Lown (1991), who estimate that changes in credit following changes in economic conditions may be modest.

${ }^{17}$ Though they were not included in Kashyap and Stein (2000), for example, we further add bank fixed effects that capture the still-unaccounted-for bank heterogeneity that is fixed over time. We report representative estimates in online Appendix G. Results are unaffected throughout, except for the coefficient on the interaction between GDP growth and bank liquidity, which turns statistically significant, and the coefficient on the interaction between the interest rate changes and bank capital, which reduces in absolute size. The latter finding is not surprising, as the largest part of variation of bank capital is between but not within banks.

${ }^{18}$ The calculations are: for the interest rate: $0.038=(0.01 \times 28.566 \times(0.035-0.084)) / 0.37$ and $0.062=(0.01$ $\times 11.548 \times(0.077-0.277)) / 0.37$; for GDP: $0.042=(-0.01 \times-31.426 \times(0.035-0.084)) / 0.37$ and 0.009 $=(-0.01 \times-1.602 \times(0.077-0.277)) / 0.37$.
} 
Table 3-Regression Results, Loan Granting and Monetary Conditions WITH Firm-MONTH OR LOAN FIXEd EFFECTS (Dependent variable: LOAN APPLICATION IS GRANTED ${ }_{i b t}$ )

\begin{tabular}{|c|c|c|c|c|}
\hline Model & (1) & $(2)$ & $(3)$ & (4) \\
\hline \multicolumn{5}{|l|}{ Macroeconomic controls $(t)$} \\
\hline$\triangle I R_{t} \times$ BANK CAPITAL RATIO $O_{b t-1}$ & $\begin{array}{l}28.566 * * * \\
(6.822)\end{array}$ & $\begin{array}{l}30.081 * * * \\
(7.737)\end{array}$ & $\begin{array}{l}19.873^{* * * *} \\
(5.681)\end{array}$ & $\begin{array}{l}49.477 * * * \\
(16.241)\end{array}$ \\
\hline $\begin{array}{l}\Delta I R_{t} \times B A N K \text { LIQUIDITY } \\
\quad \operatorname{RATIO}_{b t-1}\end{array}$ & $\begin{array}{l}11.548 * * * \\
(2.019)\end{array}$ & $\begin{array}{l}12.269^{* * * *} \\
(2.286)\end{array}$ & $\begin{array}{l}5.190^{* * * *} \\
(1.926)\end{array}$ & $\begin{array}{l}10.412 * * \\
(4.537)\end{array}$ \\
\hline $\begin{array}{l}\Delta G D P_{t} \times B A N K C A P I T A L \\
\quad R A T I O_{b t-1}\end{array}$ & $\begin{array}{c}-31.426 * * * \\
(5.669)\end{array}$ & $\begin{array}{c}-37.078 * * * \\
(5.994)\end{array}$ & $\begin{array}{l}-25.668 * * * \\
(3.175)\end{array}$ & $\begin{array}{r}-12.594 \\
(15.468)\end{array}$ \\
\hline $\begin{array}{l}\Delta G D P_{t} \times \text { BANK LIQUIDITY } \\
\quad \text { RATIO }_{b t-1}\end{array}$ & $\begin{array}{c}-1.602 \\
(2.035)\end{array}$ & $\begin{array}{c}-1.877 \\
(2.166)\end{array}$ & $\begin{array}{l}-2.375^{* *} \\
(1.109)\end{array}$ & $\begin{array}{c}6.947 \\
(4.945)\end{array}$ \\
\hline \multicolumn{5}{|l|}{ Bank characteristics $(b)$} \\
\hline BANK CAPITAL RATIO ${ }_{b t-1}$ & $\begin{array}{c}0.308^{*} \\
(0.184)\end{array}$ & $\begin{array}{l}0.389 * * \\
(0.191)\end{array}$ & $\begin{array}{c}0.175^{*} \\
(0.093)\end{array}$ & $\begin{array}{r}-0.810 \\
(0.503)\end{array}$ \\
\hline BANK LIQUIDITY RATIO ${ }_{b t-1}$ & $\begin{array}{r}-0.075 \\
(0.066)\end{array}$ & $\begin{array}{c}-0.062 \\
(0.070)\end{array}$ & $\begin{array}{r}-0.055 \\
(0.035)\end{array}$ & $\begin{array}{l}-0.489 * * * \\
(0.162)\end{array}$ \\
\hline $\ln \left(\right.$ TOTAL ASSETS $\left._{b t-1}\right)$ & $\begin{array}{c}-0.001 \\
(0.001)\end{array}$ & $\begin{array}{l}-0.003 * * * \\
(0.001)\end{array}$ & $\begin{array}{c}0.001 \\
(0.001)\end{array}$ & $\begin{array}{l}-0.006^{* * * *} \\
(0.002)\end{array}$ \\
\hline$R O A_{b t-1}$ & $\begin{array}{l}1.252 * * * \\
(0.233)\end{array}$ & $\begin{array}{l}1.355^{* * * *} \\
(0.261)\end{array}$ & $\begin{array}{l}1.434 * * * \\
(0.218)\end{array}$ & $\begin{array}{l}1.371 * * \\
(0.533)\end{array}$ \\
\hline $\begin{array}{l}\text { DOUBTFUL LOANS } \\
\quad \text { RATIO }_{b t-1}\end{array}$ & $\begin{array}{c}0.158 \\
(0.145)\end{array}$ & $\begin{array}{c}0.136 \\
(0.164)\end{array}$ & $\begin{array}{l}-0.286^{* * * *} \\
(0.088)\end{array}$ & $\begin{array}{l}-0.693 * * \\
(0.337)\end{array}$ \\
\hline HERFINDAHL BY INDUSTRY $Y_{b t-1}$ & $\begin{array}{c}0.016 \\
(0.015)\end{array}$ & $\begin{array}{c}0.018 \\
(0.017)\end{array}$ & $\begin{array}{c}0.002 \\
(0.014)\end{array}$ & $\begin{array}{c}0.056^{*} \\
(0.033)\end{array}$ \\
\hline \multicolumn{5}{|l|}{ Firm characteristics $(i)$} \\
\hline $\begin{array}{c}\ln (1+\text { NUMBER OF MONTHS } \\
\text { WITH THE BANK } \\
\text { ibt-1 })\end{array}$ & $\begin{array}{l}0.010 * * * \\
(0.001)\end{array}$ & $\begin{array}{l}0.013^{* * *} \\
(0.001)\end{array}$ & $\begin{array}{l}0.011 * * * \\
(0.001)\end{array}$ & $\begin{array}{l}0.026^{* * * *} \\
(0.004)\end{array}$ \\
\hline Firm-month fixed effects & Yes & No & Yes & Yes \\
\hline Loan fixed effects & No & Yes & No & No \\
\hline Observations & 328,891 & 263,042 & 427,364 & 55,025 \\
\hline $\begin{array}{l}\text { Number of bank-month } \\
\text { clusters }\end{array}$ & 8,714 & 8,310 & 10,637 & 6,022 \\
\hline Sample period & $\begin{array}{l}2002: 02- \\
2008: 12\end{array}$ & $\begin{array}{l}2002: 02- \\
2008: 12\end{array}$ & $\begin{array}{l}\text { 2002:02- } \\
\text { 2010:06 }\end{array}$ & $\begin{array}{l}2002: 02- \\
2008: 12\end{array}$ \\
\hline
\end{tabular}

Notes: The table reports the estimated coefficients and robust standard errors (in parentheses) clustered at the bank-month level from linear probability models estimated using least squares. The sample employed in Model (4) includes only borrowers that are noncurrent to all banks. Fixed effects are included ("yes") or not included ("no"). The set of month fixed effects includes a fixed effect for every (but one) year:month during the sample period. The variable definitions and summary statistics are in Table 1.

$* * *$ Significant at the 1 percent level.

** Significant at the 5 percent level.

* Significant at the 10 percent level.

for the same loan to different banks that resulted in at most one granted loan. The number of observations decreases to 263,042 (summary statistics are again provided in online Appendix D). Results are again very similar to Model (3) in Table 2.

The estimates are further robust to the inclusion of the recent exceptionally severe crisis period in Spain, which increases the number of observations to 427,364. The estimates are tabulated in Model (3) in Table 3. Therefore, despite the fact that monetary policy was executed in different ways during the recent crisis, the bank lending channel of monetary policy (through changes in short-term interest rates) retained its potency. 
Estimates are also robust to: The inclusion of the double balance-sheet interactions with the Herfindahl-Hirschman Index of bank lending in the province; ${ }^{19}$ the use of a logit specification (as discussed earlier, employing logit models reduces the number of observations to 155,167); the left-censoring of bank capital ratio at 4 percent (as in the United States, for example); the inclusion of interactions of the change in the short-term interest rate and GDP growth with all (other) bank characteristics; the removal of the interactions with GDP growth; and the inclusion of a variable capturing the number of loans the firm currently obtains from the bank. In each case, the estimates for at least the most-demanding, benchmark model using firm-month fixed effects are reported in online Appendices F and G.

In sum, Models (1) and (2) in Table 3 show that within the set of applications made in the same month by the same firm to different banks, and within the set of different applications made for the same loan, fewer loans are granted by banks with low capital or liquidity when short-term interest rate increases are larger or by banks with low capital when GDP growth is lower. Assuming that the very small changes in firm quality that occur during each month are not correlated with the quality of the approached banks - which is the case, for example, if firm quality is constant within each monthour results imply that under tighter macro conditions (e.g., tighter monetary policy or a recession) a capital crunch begets a credit crunch. This is a key result since Bernanke and Lown (1991, p. 207) define credit crunch as "a significant leftward shift in the supply curve for loans, holding constant both the safe real interest rate and the quality of potential borrowers" (our italicizing). As far as we are aware we are the first to identify and document in such a clear-cut way (i.e., it is the same firm that does apply at the same time or for the same loan to several banks) the occurrence of a credit crunch.

Loan Applications from Current Borrowers.-Our estimations so far focused on the probability that loan applications from noncurrent borrowers get approved. However, firms may initially apply to banks they currently don't borrow from, but if their applications fail return to their current lenders to obtain new loans there. These "applications of last resort" with current lenders will not trigger information requests because lenders automatically obtain monthly information from the CIR on all their current borrowers. Not including such applications may bias our findings.

To address this potential problem, Model (4) in Table 3 studies lending to all borrowers without any outstanding bank debt (hence, borrowers without any current lender). The estimation in Model (4) is based on 55,025 loan applications made by firms that have no bank debt outstanding at $t-1$. The coefficients on the interaction terms again confirm the existence of a bank balance sheet channel of monetary policy.

Credit Substitution.-Finally, we want to investigate whether the loan supply restrictions we identified so far are binding and cannot be fully offset by firms turning to other banks. We look at this possible substitution mechanism in two ways: (i) directly, by conditioning on firms that did not get any loan following

\footnotetext{
${ }^{19}$ If product market competition is a strong substitute for corporate governance (Giroud and Mueller 2009), then in regions with tougher competition among banks agency costs may be reduced so that the bank balance-sheet channel may be less potent. We find this to be the case for GDP-capital ratio interaction, but not for the other three interactions, suggesting that in banking more competition does not necessarily reduce moral hazard.
} 
TABLE 4-Summary Statistics

\begin{tabular}{|c|c|c|c|c|c|c|c|}
\hline Variable & Units & Definition & Mean & SD & Min & Median & $\operatorname{Max}$ \\
\hline \multicolumn{8}{|l|}{ Dependent variable } \\
\hline $\begin{array}{l}\text { FUTURE LOAN APPLICATION } \\
\text { IS GRANTED FOLLOWING } \\
\quad \text { REJECTION }_{i b t}\end{array}$ & $0 / 1$ & $\begin{array}{l}=1 \text { if at least one future loan application } \\
\text { by a firm is approved and the loan is } \\
\text { granted by a bank given that a loan } \\
\text { application was rejected during the } \\
\text { previous three months, }=0 \text { otherwise }\end{array}$ & 0.37 & 0.48 & 0 & 0 & 1 \\
\hline \multicolumn{8}{|l|}{ Independent variables } \\
\hline \multicolumn{8}{|l|}{ Macroeconomic conditions $(t)$} \\
\hline$\Delta I R_{t}$ & $\%$ & $\begin{array}{l}\text { Annual change of Spanish 3-month } \\
\text { interbank interest rates }\end{array}$ & 0.26 & 0.82 & -1.56 & 0.43 & 1.41 \\
\hline$\triangle G D P t$ & $\%$ & $\begin{array}{l}\text { Annual change of Spanish gross domes- } \\
\text { tic product in real terms }\end{array}$ & 3.01 & 1.09 & -0.85 & 3.35 & 3.98 \\
\hline$\Delta C P I_{t}$ & $\%$ & $\begin{array}{l}\text { Annual change of Spanish Consumer } \\
\text { Price Index }\end{array}$ & 3.35 & 0.84 & 1.43 & 3.40 & 5.27 \\
\hline \multicolumn{8}{|l|}{ Bank characteristics $(b)$} \\
\hline BANK CAPITAL RATIO ${ }_{b t-1}$ & $\%$ & $\begin{array}{l}\text { The ratio of bank equity over total as- } \\
\text { sets of the bank }\end{array}$ & 5.31 & 2.04 & 0.00 & 4.83 & 61.75 \\
\hline BANK LIQUIDITY RATIO ${ }_{b t-1}$ & $\%$ & $\begin{array}{l}\text { The ratio of liquid assets (cash and } \\
\text { balance with central banks, and loans } \\
\text { and advances to governments and credit } \\
\text { institutions) held by the bank over the } \\
\text { total assets of the bank }\end{array}$ & 16.50 & 7.86 & 0.04 & 15.52 & 91.62 \\
\hline $\ln \left(\right.$ TOTAL ASSETS $\left._{b t-1}\right)$ & - & The log of the total assets of the bank & 17.36 & 1.45 & 10.06 & 17.56 & 20.76 \\
\hline TOTAL ASSETS $_{b t-1}$ & $\begin{array}{l}000,000.000 \\
\text { EUR }\end{array}$ & The total assets of the bank & 76.50 & 91.00 & 0.02 & 42.40 & $1,030.00$ \\
\hline$R O A_{b t-1}$ & $\%$ & $\begin{array}{l}\text { The total net income over assets of the } \\
\text { bank }\end{array}$ & 0.93 & 0.55 & -8.93 & 0.90 & 11.92 \\
\hline DOUBTFUL LOANS RATIO $b t-1$ & $\%$ & The doubtful loan ratio of the bank & 0.90 & 0.92 & 0.00 & 0.61 & 17.36 \\
\hline HERFINDAHL BY INDUSTRY $Y_{b t-1}$ & $\%$ & $\begin{array}{l}\text { The Herfindahl-Hirschman index of the } \\
\text { bank's credit portfolio by industry }\end{array}$ & 27.21 & 9.21 & 12.77 & 24.15 & 87.94 \\
\hline \multicolumn{8}{|c|}{ Average approached bank characteristics $(b)$} \\
\hline BANK CAPITAL RATIO $O_{b t-1}$ & $\%$ & $\begin{array}{l}\text { The ratio of bank equity over total as- } \\
\text { sets of the bank }\end{array}$ & 5.25 & 1.89 & 0.00 & 4.77 & 61.75 \\
\hline BANK LIQUIDITY RATIO ${ }_{b t-1}$ & $\%$ & $\begin{array}{l}\text { The ratio of liquid assets (cash and } \\
\text { balance with central banks, and loans } \\
\text { and advances to governments and credit } \\
\text { institutions) held by the bank over the } \\
\text { total assets of the bank }\end{array}$ & 16.37 & 7.48 & 0.04 & 15.53 & 91.37 \\
\hline $\ln \left(\right.$ TOTAL ASSETS $\left._{b t-1}\right)$ & - & The log of the total assets of the bank & 17.49 & 1.39 & 10.14 & 17.69 & 20.76 \\
\hline TOTAL ASSETS $_{b t-1}$ & $\begin{array}{l}000,000.000 \\
\text { EUR }\end{array}$ & The total assets of the bank & 80.80 & 91.20 & 0.03 & 48.20 & 1040.00 \\
\hline$R O A_{b t-1}$ & $\%$ & The return on assets of the bank & 0.93 & 0.50 & -8.93 & 0.89 & 11.92 \\
\hline DOUBTFUL LOANS RATIO ${ }_{b t-1}$ & $\%$ & The doubtful loan ratio of the bank & 0.96 & 1.01 & 0.00 & 0.62 & 31.24 \\
\hline HERFINDAHL BY INDUSTRY $Y_{b t-1}$ & $\%$ & $\begin{array}{l}\text { The Herfindahl-Hirschman index of the } \\
\text { bank's credit portfolio by industry }\end{array}$ & 27.10 & 8.69 & 13.88 & 24.45 & 86.67 \\
\hline
\end{tabular}

(Continued)

an initial round of loan applications, and then determining whether such a firm receives a loan from an alternative bank after a new round of applications in the subsequent three months; (ii) indirectly, by analyzing whether a firm gets a bank loan from any bank (including its current lenders) given that the firm has at least one loan application.

The first dependent variable is FUTURE LOAN APPLICATION IS GRANTED FOLLOWING REJECTION, which equals one if at least one loan application by a firm within three months is approved and the loan is granted by a bank given that loan applications did not result in a loan, and equals zero otherwise. The upper panel in Table 4 provides the summary statistics for the 117,152 observations. The probability that at least one application within three months following a rejection is successful equals 37 percent. 
TABle 4-Summary Statistics (Continued)

\begin{tabular}{|c|c|c|c|c|c|c|c|}
\hline Variable & Units & Definition & Mean & SD & Min & Median & Max \\
\hline \multicolumn{8}{|l|}{ Dependent variable } \\
\hline $\begin{array}{l}\text { FUTURE LOAN APPLICATION } \\
\text { IS GRANTED AFTER } \\
\text { EARLIER APPLICATION IS } \\
\text { MADE }_{\text {ibt }}\end{array}$ & $0 / 1$ & $\begin{array}{l}=1 \text { if at least one future loan application } \\
\text { by a firm is approved and the loan is } \\
\text { granted by a bank given that a loan ap- } \\
\text { plication was made during the previous } \\
\text { three months, }=0 \text { otherwise }\end{array}$ & 0.79 & 0.41 & 0 & 1 & 1 \\
\hline \multicolumn{8}{|l|}{ Independent variables } \\
\hline \multicolumn{8}{|l|}{ Macroeconomic conditions $(t)$} \\
\hline$\Delta I R_{t}$ & $\%$ & $\begin{array}{l}\text { Annual change of Spanish 3-month } \\
\text { interbank interest rates }\end{array}$ & 0.18 & 0.83 & -1.56 & 0.11 & 1.41 \\
\hline$\Delta G D P_{t}$ & $\%$ & $\begin{array}{l}\text { Annual change of Spanish gross domes- } \\
\text { tic product in real terms }\end{array}$ & 3.13 & 0.92 & -0.85 & 3.35 & 3.98 \\
\hline$\Delta C P I_{t}$ & $\%$ & $\begin{array}{l}\text { Annual change of Spanish Consumer } \\
\text { Price Index }\end{array}$ & 3.32 & 0.77 & 1.43 & 3.40 & 5.27 \\
\hline \multicolumn{8}{|l|}{ Bank characteristics $(b)$} \\
\hline BANK CAPITAL RATIO $O_{b t-1}$ & $\%$ & $\begin{array}{l}\text { The ratio of bank equity over total as- } \\
\text { sets of the bank }\end{array}$ & 5.66 & 1.27 & 0.00 & 5.49 & 50.03 \\
\hline BANK LIQUIDITY RATIO ${ }_{b t-1}$ & $\%$ & $\begin{array}{l}\text { The ratio of liquid assets (cash and } \\
\text { balance with central banks, and loans } \\
\text { and advances to governments and credit } \\
\text { institutions) held by the bank over the } \\
\text { total assets of the bank }\end{array}$ & 16.88 & 5.35 & 0.04 & 16.22 & 91.21 \\
\hline $\ln \left(\right.$ TOTAL ASSETS $\left._{b t-1}\right)$ & - & The log of the total assets of the bank & 18.07 & 0.88 & 9.91 & 18.27 & 19.90 \\
\hline TOTAL ASSETS $_{b t-1}$ & $\begin{array}{l}000,000.000 \\
\text { EUR }\end{array}$ & The total assets of the bank & 91.90 & 56.30 & 0.02 & 86.20 & 437.00 \\
\hline$R O A_{b t-1}$ & $\%$ & $\begin{array}{l}\text { The total net income over assets of the } \\
\text { bank }\end{array}$ & 1.02 & 0.33 & -8.93 & 1.00 & 5.25 \\
\hline DOUBTFUL LOANS RATIO $O_{b t-1}$ & $\%$ & The doubtful loan ratio of the bank & 0.81 & 0.60 & 0.00 & 0.63 & 20.50 \\
\hline HERFINDAHL BY INDUSTR $Y_{b t-1}$ & $\%$ & $\begin{array}{l}\text { The Herfindahl-Hirschman index of the } \\
\text { bank's credit portfolio by industry }\end{array}$ & 26.07 & 6.21 & 13.44 & 25.30 & 81.02 \\
\hline \multicolumn{8}{|l|}{ Selected firm characteristics $(i)$} \\
\hline $\begin{array}{l}\text { NUMBER OF BANK } \\
\quad \text { RELATIONSHIPS }_{i b t-1}\end{array}$ & - & $\begin{array}{l}\text { The number of bank relationships of } \\
\text { the firm }\end{array}$ & 3.66 & 3.47 & 0 & 3 & 102 \\
\hline $\begin{array}{l}\ln (1+\text { NUMBER OF BANK } \\
\left.\text { RELATIONSHIPS }_{i b t-1}\right)\end{array}$ & - & $\begin{array}{l}\text { The log of the number of bank relation- } \\
\text { ships of the firm }\end{array}$ & 1.33 & 0.64 & 0 & 1.39 & 4.63 \\
\hline
\end{tabular}

Notes: The number of observations equals 117,152 in the top panel and 746,341 in the bottom panel. EUR $=2008$ euros.

We are interested in knowing both whether credit substitution is more difficult during periods of tighter monetary policy or worse economic conditions, and whether this process is affected by the strength of bank balance sheets. We control for the balance-sheet quality of the assessing bank and of the average bank approached by the firm (indexed $\mathbf{b}$ ), and as before for firm, industry, and province characteristics (to conserve space these estimates are left unreported). Table 5 displays two representative models: Model (1) features firm fixed effects, Model (2) firm and month fixed effects. ${ }^{20}$

The estimated coefficients indicate that an increase in the interest rate or a decrease in GDP growth increases the probability that subsequent loan applications by a firm will be rejected (especially when the bank is weakly capitalized or liquid). ${ }^{21}$

Next, we analyze the second variable, called FUTURE LOAN APPLICATION IS GRANTED AFTER EARLIER APPLICATION IS MADE, which equals one if at least one loan is granted by any bank to a firm within the next three months given

\footnotetext{
${ }^{20}$ Obviously, it is not possible to answer this set of questions with firm-time fixed effects.

${ }^{21}$ The difference in semielasticities for a 100-basis point increase (decrease) in the interest rate (GDP growth) between low and high bank capital and liquidity ratios equals $1.3(2.5)$ and $4.9(0.2)$ percent, respectively.
} 
Table 5-Regression Results, LoAn GRanting and Past Rejections (Dependent variable: FUTURE LOAN APPLICATION IS GRANTED FOLLOWING REJECTION ${ }_{i b t}$ )

\begin{tabular}{|c|c|c|}
\hline Model & $(1)$ & $(2)$ \\
\hline \multicolumn{3}{|l|}{ Macroeconomic controls $(t)$} \\
\hline$\Delta I R_{t}$ & $\begin{array}{c}-7.083 * * * \\
(1.407)\end{array}$ & \\
\hline$\Delta I R_{t} \times B A N K C A P I T A L R A T I O_{b t-1}$ & $\begin{array}{l}23.892 * * \\
(10.967)\end{array}$ & $\begin{array}{c}17.980 * \\
(10.618)\end{array}$ \\
\hline$\Delta I R_{t} \times B A N K L I Q U I D I T Y R A T I O_{b t-1}$ & $\begin{array}{l}23.888 * * * \\
(4.175)\end{array}$ & $\begin{array}{l}15.367 * * * \\
(3.548)\end{array}$ \\
\hline$\Delta G D P_{t}$ & $\begin{array}{l}5.451 * * * \\
(0.857)\end{array}$ & \\
\hline$\triangle G D P_{t} \times B A N K C A P I T A L R A T I O_{b t-1}$ & $\begin{array}{c}-33.757 * * * \\
(9.170)\end{array}$ & $\begin{array}{c}-34.035 * * * \\
(9.403)\end{array}$ \\
\hline$\Delta G D P_{t} \times B A N K$ LIQUIDITY RATIO ${ }_{b t-1}$ & $\begin{array}{c}0.169 \\
(2.944)\end{array}$ & $\begin{array}{r}-0.070 \\
(2.549)\end{array}$ \\
\hline$\Delta C P I_{t}$ & $\begin{array}{c}-1.363^{* *} \\
(0.553)\end{array}$ & \\
\hline \multicolumn{3}{|l|}{ Bank characteristics $(b)$} \\
\hline BANK CAPITAL RATIO $O_{b t-1}$ & $\begin{array}{c}0.084 \\
(0.095)\end{array}$ & $\begin{array}{c}0.035 \\
(0.093)\end{array}$ \\
\hline BANK LIQUIDITY RATIO ${ }_{b t-1}$ & $\begin{array}{r}-0.019 \\
(0.027)\end{array}$ & $\begin{array}{r}-0.016 \\
(0.027)\end{array}$ \\
\hline $\ln \left(\right.$ TOTAL ASSETS $\left._{b t-1}\right)$ & $\begin{array}{c}0.001 \\
(0.001)\end{array}$ & $\begin{array}{c}0.001 \\
(0.001)\end{array}$ \\
\hline$R O A_{b t-1}$ & $\begin{array}{c}-0.052 \\
(0.270)\end{array}$ & $\begin{array}{c}0.248 \\
(0.278)\end{array}$ \\
\hline DOUBTFUL LOANS RATIO ${ }_{b t-1}$ & $\begin{array}{c}-0.362 \\
(0.227)\end{array}$ & $\begin{array}{r}-0.240 \\
(0.240)\end{array}$ \\
\hline HERFINDAHL BY INDUSTRY $Y_{b t-1}$ & $\begin{array}{c}0.034 \\
(0.028)\end{array}$ & $\begin{array}{c}0.040 \\
(0.025)\end{array}$ \\
\hline \multicolumn{3}{|l|}{ Average approached bank characteristics $(b)$} \\
\hline BANK CAPITAL RATIO ${ }_{b t-1}$ & $\begin{array}{l}1.083^{* * * *} \\
(0.287)\end{array}$ & $\begin{array}{l}1.051 * * * \\
(0.294)\end{array}$ \\
\hline BANK LIQUIDITY RATIO ${ }_{b t-1}$ & $\begin{array}{r}-0.016 \\
(0.089)\end{array}$ & $\begin{array}{r}-0.002 \\
(0.077)\end{array}$ \\
\hline $\ln \left(\right.$ TOTAL ASSETS $\left._{b t-1}\right)$ & $\begin{array}{l}0.037 * * * \\
(0.002)\end{array}$ & $\begin{array}{l}0.036^{* * * *} \\
(0.002)\end{array}$ \\
\hline$R O A_{b t-1}$ & $\begin{array}{l}0.952 * * \\
(0.437)\end{array}$ & $\begin{array}{l}1.339 * * * \\
(0.417)\end{array}$ \\
\hline DOUBTFUL LOANS RATIO ${ }_{b t-1}$ & $\begin{array}{l}1.038^{* * * *} \\
(0.341)\end{array}$ & $\begin{array}{l}1.061 * * * \\
(0.306)\end{array}$ \\
\hline HERFINDAHL BY INDUSTRY $Y_{b t-1}$ & $\begin{array}{l}0.111^{* * * *} \\
(0.029)\end{array}$ & $\begin{array}{l}0.094 * * * \\
(0.030)\end{array}$ \\
\hline
\end{tabular}

that a loan application was made in that month, and equals zero otherwise. The number of observations increases to 746,341 (from 117,152 ), while the mean probability that a loan is granted increases to 79 percent (from 37 percent).

Table 6 displays representative models with firm fixed effects (1) and with firm and month fixed effects (2). We find that higher interest rates or lower GDP growth reduce the probability of obtaining any bank loans, after an initial loan application by a firm is made (and, for monetary policy, these effects are stronger for weaker banks). 
Table 5-Regression Results, Loan Granting and Past Rejections (Dependent variable: FUTURE LOAN APPLICATION IS GRANTED FOLLOWING REJECTION $\left.{ }_{\text {ibt }}\right)$ (Continued)

\begin{tabular}{lcc}
\hline \hline Model & $(1)$ & $(2)$ \\
\hline Selected firm characteristics $(i)$ & & $-0.165^{* * * *}$ \\
$\ln \left(1+\right.$ NUMBER OF BANK RELATIONSHIPS ibt $\left.-1_{1}\right)$ & $(0.010)$ & $(0.010)$ \\
& Yes \\
Other firm $(i)$, industry $(s)$, and province $(p)$ characteristics, constant & Yes & Yes \\
Firm fixed effects & Yes & Yes \\
Month fixed effects & No & 117,152 \\
Observations & 117,152 & 83 \\
Number of month clusters & 83 & $2002: 02-2008: 12$ \\
Period & $2002: 02-2008: 12$ & 2002 \\
\hline
\end{tabular}

Notes: The table reports the estimated coefficients and robust standard errors (in parentheses) clustered at the monthly level from linear probability models estimated using least squares. The set of included bank $(b)$, firm $(i)$, industry $(s)$, and province $(p)$ characteristics is the same as in Table 2. Fixed effects are included ("yes") or not included ("no"). The set of month fixed effects includes a fixed effect for every (but one) year:month during the sample period. The variable definitions and summary statistics of selected variables are in Table 1 .

*** Significant at the 1 percent level.

** Significant at the 5 percent level.

* Significant at the 10 percent level.

All in all, from the two models we find that a firm cannot simply turn to other banks to undo a rejection of a loan application that is due to tightening monetary or economic conditions channeled.

We interact in Models (3) and (4) the number of bank relationships (which equals the number of banks the firm is currently borrowing from) with the change in the interest rate or GDP growth, and with bank capital or liquidity. That is, we examine whether the bank lending channel is less potent as the banking relationship is stronger.

Results are striking and take one additional last step in identifying a bank balance-sheet channel. The estimated coefficients on the newly introduced double and triple interactions are not only statistically significant, but also economically meaningful (online Appendix $\mathrm{H}$ ). Improving conditions increase the difference between the loan granting probabilities of weak and strong banks, but this effect is mitigated for firms that are engaged with several banks. For firms that are engaged with three banks the difference is one-third the difference for firms that currently do not have a bank relationship.

\section{Conclusions and Policy Implications}

Does the stance of monetary policy and business cycle fluctuations affect credit supply? And, if so, how relevant is the bank balance-sheet channel? These questions are not only key for macroeconomics in general, but also for policymaking (the handling of the current crisis in particular). However, to answer these questions there are two main identification challenges: (i) Monetary and economic conditions affect both credit demand and supply. (ii) Separating the effects of monetary conditions and economic activity is also problematic as short-term interest rate changes may be completely determined by the business cycle. 
TABle 6-Regression Results, LoAn Granting and Past ApPlications (Dependent variable: FUTURE LOAN APPLICATION IS GRANTED AFTER EARLIER APPLICATION IS MADE $E_{i b t}$ )

\begin{tabular}{|c|c|c|c|c|}
\hline Model & (1) & (2) & (3) & $(4)$ \\
\hline \multicolumn{5}{|l|}{ Macroeconomic controls $(t)$} \\
\hline$\Delta I R_{t}$ & $\begin{array}{l}-3.184 * * * \\
(0.743)\end{array}$ & & $\begin{array}{l}-5.781 * * * \\
(1.344)\end{array}$ & \\
\hline$\Delta I R_{t} \times B A N K C A P I T A L R A T I O_{b t-1}$ & $\begin{array}{l}12.337 * \\
(7.007)\end{array}$ & $\begin{array}{l}12.486^{*} \\
(6.942)\end{array}$ & $\begin{array}{l}39.628 * * \\
(16.046)\end{array}$ & $\begin{array}{l}37.993 * * \\
(15.600)\end{array}$ \\
\hline$\Delta I R_{t} \times$ BANK LIQUIDITY RATIO $O_{b t-1}$ & $\begin{array}{l}7.491 * * * \\
(2.146)\end{array}$ & $\begin{array}{l}6.643 * * * \\
(1.679)\end{array}$ & $\begin{array}{l}14.740 * * * \\
(4.310)\end{array}$ & $\begin{array}{l}13.292 * * * \\
(3.995)\end{array}$ \\
\hline$\Delta G D P_{t}$ & $\begin{array}{l}4.968 * * * \\
(0.545)\end{array}$ & & $\begin{array}{l}8.162^{* * *} \\
(1.156)\end{array}$ & \\
\hline$\Delta G D P_{t} \times B A N K C A P I T A L R A T I O_{b t-1}$ & $\begin{aligned}- & 35.679 * * * \\
& (5.784)\end{aligned}$ & $\begin{array}{l}-31.473 * * * \\
(5.431)\end{array}$ & $\begin{array}{l}-87.526 * * * \\
(17.132)\end{array}$ & $\begin{array}{l}-83.131 * * * \\
(16.768)\end{array}$ \\
\hline$\Delta G D P_{t} \times B A N K L I Q U I D I T Y$ RATIO ${ }_{b t-1}$ & $\begin{array}{l}-7.539 * * * \\
(2.283)\end{array}$ & $\begin{array}{l}-3.200 * * \\
(1.486)\end{array}$ & $\begin{array}{c}0.757 \\
(4.639)\end{array}$ & $\begin{array}{c}4.614 \\
(4.260)\end{array}$ \\
\hline$\triangle C P I_{t}$ & $\begin{array}{c}-0.078 \\
(0.123)\end{array}$ & & $\begin{array}{c}-0.099 \\
(0.120)\end{array}$ & \\
\hline \multicolumn{5}{|l|}{ Bank characteristics $(b)$} \\
\hline BANK CAPITAL RATIO & $\begin{array}{l}1.284 * * * \\
(0.198)\end{array}$ & $\begin{array}{l}1.061 * * * \\
(0.188)\end{array}$ & $\begin{array}{l}2.988 * * * \\
(0.592)\end{array}$ & $\begin{array}{l}2.844 * * * \\
(0.577)\end{array}$ \\
\hline BANK LIQUIDITY RATIO $O_{b t-1}$ & $\begin{array}{l}0.224 * * * \\
(0.080)\end{array}$ & $\begin{array}{c}0.041 \\
(0.054)\end{array}$ & $\begin{array}{r}-0.109 \\
(0.153)\end{array}$ & $\begin{array}{r}-0.229 \\
(0.139)\end{array}$ \\
\hline $\ln \left(\right.$ TOTAL ASSETS $\left._{b t-1}\right)$ & $\begin{array}{l}0.003 * * * \\
(0.001)\end{array}$ & $\begin{array}{l}0.007 * * * \\
(0.001)\end{array}$ & $\begin{array}{l}0.003 * * * \\
(0.001)\end{array}$ & $\begin{array}{l}0.007 * * * \\
(0.001)\end{array}$ \\
\hline$R O A_{b t-1}$ & $\begin{array}{c}0.171 \\
(0.203)\end{array}$ & $\begin{array}{l}0.691 * * * \\
(0.196)\end{array}$ & $\begin{array}{c}0.111 \\
(0.203)\end{array}$ & $\begin{array}{l}0.624 * * * \\
(0.198)\end{array}$ \\
\hline DOUBTFUL LOANS RATIO ${ }_{b t-1}$ & $\begin{array}{c}0.282 \\
(0.182)\end{array}$ & $\begin{array}{c}0.132 \\
(0.179)\end{array}$ & $\begin{array}{c}0.222 \\
(0.183)\end{array}$ & $\begin{array}{c}0.098 \\
(0.181)\end{array}$ \\
\hline HERFINDAHL BY INDUSTRY $Y_{b t-1}$ & $\begin{array}{c}-0.026 \\
(0.020)\end{array}$ & $\begin{array}{l}0.073 * * * \\
(0.020)\end{array}$ & $\begin{array}{c}-0.013 \\
(0.019)\end{array}$ & $\begin{array}{l}0.075^{* * *} \\
(0.020)\end{array}$ \\
\hline \multicolumn{5}{|l|}{ Selected firm characteristics $(i)$} \\
\hline $\ln \left(1+\right.$ NUMBER OF BANK RELATIONSHIPS $\left.S_{i b t-1}\right)$ & $\begin{array}{r}-0.002 \\
(0.003)\end{array}$ & $\begin{array}{c}-0.001 \\
(0.003)\end{array}$ & $\begin{array}{l}0.059 * * \\
(0.023)\end{array}$ & $\begin{array}{l}0.070^{* * *} \\
(0.024)\end{array}$ \\
\hline \multicolumn{5}{|l|}{ Interactions with $\ln (1+$ NUMBER OF BANK RELATIONSHIPS $)$} \\
\hline $\begin{array}{l}\Delta I R_{t} \times \ln (1+N U M B E R \text { OF BANK } \\
\quad \text { RELATIONSHIPS } \text { ibt-1 })\end{array}$ & & & $\begin{array}{l}2.193^{* * *} \\
(0.681)\end{array}$ & $\begin{array}{l}2.004 * * \\
(0.827)\end{array}$ \\
\hline $\begin{array}{l}\Delta I R_{t} \times \text { BANK CAPITAL RATIO }_{b t-1} \\
\quad \times \ln (1+\text { NUMBER OF BANK } \\
\left.\quad \text { RELATIONSHIPS }_{i b t-1}\right)\end{array}$ & & & $\begin{array}{c}-21.042 * * \\
(9.284)\end{array}$ & $\begin{array}{c}-19.165^{* *} \\
(9.320)\end{array}$ \\
\hline $\begin{array}{l}\Delta \text { IR }_{t} \times \text { BANK LIQUIDITY RATIO }_{b t-1} \\
\quad \times \ln (1+\text { NUMBER OF BANK } \\
\left.\quad \text { RELATIONSHIPS }_{i b t-1}\right)\end{array}$ & & & $\begin{array}{c}-6.127 * * \\
(2.517)\end{array}$ & $\begin{array}{c}-5.780^{*} \\
(2.959)\end{array}$ \\
\hline $\begin{array}{l}\Delta \text { GDP }_{t} \times \ln (1+N U M B E R \text { OF BANK } \\
\left.\quad \text { RELATIONSHIPS }_{i b t-1}\right)\end{array}$ & & & $\begin{array}{l}-2.304 * * * \\
(0.657)\end{array}$ & $\begin{array}{l}-2.275^{* * *} \\
(0.711)\end{array}$ \\
\hline $\begin{array}{l}\Delta \text { GDP }_{t} \times \text { BANK CAPITAL RATIO }_{b t-1} \\
\quad \times \ln (1+\text { NUMBER OF BANK } \\
\left.\quad \text { RELATIONSHIPS }_{i b t-1}\right)\end{array}$ & & & $\begin{array}{l}39.880 * * * \\
(11.314)\end{array}$ & $\begin{array}{l}39.325^{* * *} \\
(11.185)\end{array}$ \\
\hline $\begin{array}{l}\Delta G D P_{t} \times \text { BANK LIQUIDITY RATIO }_{b t-1} \\
\quad \times \ln (1+\text { NUMBER OF BANK } \\
\quad \text { RELATIONSHIPS } \\
\quad \text { ibt-1 }\end{array}$ & & & $\begin{array}{c}-6.113 * * \\
(2.805)\end{array}$ & $\begin{array}{l}-5.908 * * \\
(2.870)\end{array}$ \\
\hline $\begin{array}{l}\ln (1+\text { NUMBER OF BANK RELATIONSHIPS } \\
\left.\quad \times \text { BANK CAPITAL }_{i b A T I O}\right) \\
\quad \text { BAt }^{-1}\end{array}$ & & & $\begin{array}{l}-1.295^{* * * *} \\
(0.391)\end{array}$ & $\begin{array}{l}-1.355^{* * *} \\
(0.384)\end{array}$ \\
\hline $\begin{array}{l}\ln (1+\text { NUMBER OF BANK RELATIONSHIPS } \\
\left.\quad \times \text { BANK LIQUIDITY RATIO }_{b t-1}\right)\end{array}$ & & & $\begin{array}{l}0.263 * * * \\
(0.089)\end{array}$ & $\begin{array}{l}0.215^{* *} \\
(0.089)\end{array}$ \\
\hline
\end{tabular}


Table 6-Regression Results, Loan Granting and Past Applications (Dependent variable: FUTURE LOAN APPLICATION IS GRANTED AFTER EARLIER APPLICATION IS MADE $E_{i b t}$ ) (Continued)

\begin{tabular}{|c|c|c|c|c|}
\hline Model & (1) & (2) & (3) & (4) \\
\hline $\begin{array}{l}\text { Other firm }(i) \text {, industry }(s) \text {, and province }(p) \\
\text { characteristics, constant }\end{array}$ & Yes & Yes & Yes & Yes \\
\hline Firm fixed effects & Yes & Yes & Yes & Yes \\
\hline Month fixed effects & No & Yes & No & Yes \\
\hline Observations & 746,341 & 746,341 & 746,341 & 746,341 \\
\hline Number of month clusters & 83 & 83 & 83 & 83 \\
\hline Period & $\begin{array}{l}2002: 02- \\
2008: 12\end{array}$ & $\begin{array}{c}2002: 02- \\
2008: 12\end{array}$ & $\begin{array}{c}2002: 02- \\
2008: 12\end{array}$ & $\begin{array}{l}2002: 02- \\
2008: 12\end{array}$ \\
\hline
\end{tabular}

Notes: The table reports the estimated coefficients and robust standard errors (in parentheses) clustered at the monthly level from linear probability models estimated using least squares. The set of included bank $(b)$, firm $(i)$, industry $(s)$, and province $(p)$ characteristics is the same as in Table 2. Fixed effects are included ("yes") or not included ("no"). The set of month fixed effects includes a fixed effect for every (but one) year:month during the sample period. The variable definitions and summary statistics of selected variables are in Table 1 .

*** Significant at the 1 percent level.

** Significant at the 5 percent level.

* Significant at the 10 percent level.

Our contribution to the literature lies in meeting these two identification challenges. We use a unique and comprehensive loan-level dataset that is managed by the bank supervisor in Spain. The dataset contains for the last nine years all monthly information requests by banks following loan applications from firms that are currently not borrowing from them (we also use the information on all granted loans to nonfinancial firms by all credit institutions data for the last 20 years in robustness). This dataset helps us to separate loan supply from demand. Spain is a bankdominated country with pronounced business cycles including a severe contraction under way and a fairly exogenous monetary policy.

We analyze the extensive margin of lending with loan applications and find the following two results: (i) Higher short-term interest rates or lower GDP growth reduce loan granting. (ii) The negative effect of higher short-term interest rates or lower GDP growth on credit availability is stronger for banks with low capital or liquidity. Hence, the monetary policy and the business cycle effects work through a bank lending channel. Moreover, within the set of different applications from the same firm in the same month or for the same loan to different banks (i.e., keeping constant the quality of potential borrowers), we find that banks with low capital or liquidity grant fewer loans when short-term interest rates are higher or GDP growth is lower. Therefore, our results suggest that, under tighter monetary and economic conditions, a reduction in bank capital begets a credit crunch. Finally, we investigate whether the so-identified loan supply restrictions are binding and cannot be offset by firms turning to other banks. We find they cannot, especially not by firms that have no or few existing bank relationships.

As our estimates indicate the bank lending channel is potent, the implications of our analysis for both theory and policy are generally obvious and immediate. In particular, given that we find that expansive monetary policy has more potency when bank balance sheets are weak, during a crisis like the recent one the use of monetary policy rates to support credit supply seems advisable. 


\section{REFERENCES}

Ai, Chunrong, and Edward C. Norton. 2003. "Interaction Terms in Logit and Probit Models." Economics Letters 80 (1): 123-29.

Angeloni, Ignazio, Anil K. Kashyap, and Benoit Mojon, eds. 2003. Monetary Policy Transmission in the Euro Area: A Study by the Eurosystem Monetary Transmission Network. New York: Cambridge University Press.

-Ashcraft, Adam B. 2006. "New Evidence on the Lending Channel." Journal of Money, Credit, and Banking 38 (3): 751-75.

Banco de España. 1997. La Politica Monetaria Y La Inflation En España (Monetary Policy and Inflation in Spain). Madrid: Alianza Editorial.

Bernanke, Ben S. 2007. "The Financial Accelerator and the Credit Channel." Paper presented at the Atlanta Federal Reserve Bank conference on the The Credit Channel of Monetary Policy in the 21st Century, Atlanta, GA.

Bernanke, Ben S., and Alan S. Blinder. 1988. "Credit, Money, and Aggregate Demand." American Economic Review 78 (2): 435-39.

Bernanke, Ben S., and Alan S. Blinder. 1992. "The Federal Funds Rate and the Channels of Monetary Transmission." American Economic Review 82 (4): 901-21.

Bernanke, Ben S., and Mark Gertler. 1987. "Banking and Macroeconomic Equilibrium." In New Approaches to Monetary Economics: Proceedings of the Second International Symposium in Economic Theory and Econometrics, edited by W. A. Barnett and K. J. Singleton, 89-111. International Symposia in Economic Theory and Econometrics Series. New York: Cambridge University Press.

Bernanke, Ben, and Mark Gertler. 1989. "Agency Costs, Net Worth, and Business Fluctuations." American Economic Review 79 (1): 14-31.

Bernanke, Ben S., and Mark Gertler. 1995. "Inside the Black Box: The Credit Channel of Monetary Policy Transmission." Journal of Economic Perspectives 9 (4): 27-48.

Bernanke, Ben S., and Cara S. Lown. 1991. "The Credit Crunch." Brookings Papers on Economic Activity (2): 204-39.

-Bernanke, Ben S., and Ilian Mihov. 1998. "Measuring Monetary Policy." Quarterly Journal of Economics 113 (3): 869-902.

Bernanke, Ben S., Mark Gertler, and Simon Gilchrist. 1996. "The Financial Accelerator and the Flight to Quality." Review of Economics and Statistics 78 (1): 1-15.

Bernanke, Ben S., Mark Gertler, and Simon Gilchrist. 1999. "The Financial Accelerator in a Quantitative Business Cycle Framework." In Handbook of Macroeconomics Volume 1C, edited by J. B. Taylor and M. Woodford, 1341-93. Handbooks in Economics, vol. 15. New York: Elsevier Science, North-Holland.

Black, Lamont K., Diana Hancock, and Wayne Passmore. 2009. "Core Deposit Funding of Subprime Mortgages and the Effect of Monetary Policy." Unpublished.

Boivin, Jean, Michael T. Kiley, and Frederic S. Mishkin. 2010. "How Has the Monetary Transmission Mechanism Evolved Over Time?" In Handbook of Monetary Economics, edited by Benjamin M. Friedman and Michael Woodford, 369-422. New York: Elsevier.

Boschen, John F., and Leonard O. Mills. 1995. "The Relation between Narrative and Money Market Indicators of Monetary Policy." Economic Inquiry 33 (1): 24-44.

-Cameron, A. Colin, Jonah B. Gelbach, and Douglas L. Miller. 2011. "Robust Inference with Multi-way Clustering." Journal of Business and Economic Statistics 29 (2): 238-49.

Chaney, Thomas, David Sraer, and David Thesmar. 2009. "The Collateral Channel: How Real Estate Shocks Affect Corporate Investment." Unpublished.

Degryse, Hans, Moshe Kim, and Steven Ongena. 2009. Microeconometrics of Banking: Methods, Applications, and Results. New York: Oxford University Press.

Delgado, J., V. Salas, and J. Saurina. 2007. "Joint Size and Ownership Specialization in Bank Lending." Journal of Banking and Finance 31 (12): 3563-83.

Dell'Ariccia, Giovanni, and Robert Marquez. 2006. "Lending Booms and Lending Standards." Journal of Finance 61 (5): 2511-46.

Diamond, Douglas W., and Raghuram G. Rajan. 2011. "Fear of Fire Sales, Illiquidity Seeking, and Credit Freezes." Quarterly Journal of Economics 126 (2): 557-91.

Freixas, Xavier, and Jean-Charles Rochet. 2008. Microeconomics of Banking. Second ed. Cambridge, MA: MIT Press.

Gan, Jie. 2007. "The Real Effects of Asset Market Bubbles: Loan- and Firm-Level Evidence of a Lending Channel." Review of Financial Studies 20 (6): 1941-73. 
Gertler, Mark, and Simon Gilchrist. 1993. "The Role of Credit Market Imperfections in the Monetary Transmission Mechanism: Arguments and Evidence.” Scandinavian Journal of Economics 95 (1): 43-64.

Gertler, Mark, and Simon Gilchrist. 1994. "Monetary Policy, Business Cycles, and the Behavior of Small Manufacturing Firms." Quarterly Journal of Economics 109 (2): 309-40.

Gertler, Mark, and Nobuhiro Kiyotaki. 2010. "Financial Intermediation and Credit Policy in Business Cycle Analysis." In Handbook of Monetary Economics, edited by Benjamin M. Friedman and Michael Woodford, 547-99. New York: Elsevier, North-Holland.

Giannone, Domenico, Michele Lenza, and Lucrezia Reichlin. 2010. "Business Cycles in the Euro Area." In Europe and the Euro, edited by Alberto Alesina and Francesco Giavazzi, 141-67. A National Bureau of Economic Research Conference Report. Chicago: University of Chicago Press.

Giroud, Xavier, and Holger M. Mueller. 2009. "Does Corporate Governance Matter in Competitive Industries?" Journal of Financial Economics 95 (3): 312-31.

Holmstrom, Bengt, and Jean Tirole. 1997. "Financial Intermediation, Loanable Funds, and the Real Sector." Quarterly Journal of Economics 112 (3): 663-91.

Holmstrom, Bengt, and Jean Tirole. 1998. "Private and Public Supply of Liquidity." Journal of Political Economy 106 (1): 1-40.

-Jayaratne, Jith, and Donald P. Morgan. 2000. "Capital Market Frictions and Deposit Constraints at Banks." Journal of Money, Credit, and Banking 32 (1): 74-92.

JJensen, Michael C., and William H. Meckling. 1976. "Theory of the Firm: Managerial Behavior, Agency Costs and Ownership Structure.” Journal of Financial Economics 3 (4): 305-60.

-Jiménez, Gabriel, Vicente Salas, and Jesús Saurina. 2006. "Determinants of Collateral." Journal of Financial Economics 81 (2): 255-81.

Jiménez, Gabriel, Steven Ongena, José-Luis Peydró, and Jesús Saurina. 2008. "Hazardous Times for Monetary Policy: What do Twenty-three Million Bank Loans Say about the Effects of Monetary Policy on Credit Risk-taking?" Banco de Espana Working Paper 0833.

-Jiménez, Gabriel, Steven Ongena, José-Luis Peydró, and Jesús Saurina. 2012. "Credit Supply and Monetary Policy: Identifying the Bank Balance-Sheet Channel with Loan Applications: Dataset." American Economic Review. http://dx.doi.org/10.1257/aer.102.5.2301.

Kashyap, Anil K., and Jeremy C. Stein. 2000. "What Do a Million Observations on Banks Say about the Transmission of Monetary Policy?" American Economic Review 90 (3): 407-28.

Khwaja, Asim Ijaz, and Atif Mian. 2008. "Tracing the Impact of Bank Liquidity Shocks: Evidence from an Emerging Market.” American Economic Review 98 (4): 1413-42.

Kishan, Ruby P., and Timothy P. Opiela. 2000. "Bank Size, Bank Capital, and the Bank Lending Channel." Journal of Money, Credit, and Banking 32 (1): 121-41.

-Matsuyama, Kiminori. 2007. "Credit Traps and Credit Cycles.” American Economic Review 97 (1): 503-16.

Moulton, Brent R. 1986. "Random Group Effects and the Precision of Regression Estimates.” Journal of Econometrics 32 (3): 385-97.

Norton, Edward C., Hua Wang, and Chunrong Ai. 2004. "Computing Interaction Effects and Standard Errors in Logit and Probit Models.” Stata Journal 4 (2): 154-67.

Petersen, Mitchell A. 2009. "Estimating Standard Errors in Finance Panel Datasets: Comparing Approaches." Review of Financial Studies 22 (1): 435-80.

Petersen, Mitchell A., and Raghuram G. Rajan. 1994. "The Benefits of Lending Relationships: Evidence from Small Business Data.” Journal of Finance 49 (1): 3-37.

Puri, Manju, Joerg Rocholl, and Sascha Steffen. 2011. "Global Retail Lending in the Aftermath of the US Financial Crisis: Distinguishing Between Supply and Demand Effects.” Journal of Financial Economics 100 (3): 556-78.

- Ruckes, Martin. 2004. "Bank Competition and Credit Standards." Review of Financial Studies 17 (4): 1073-1102.

Stiglitz, Joseph E., and Andrew Weiss. 1981. "Credit Rationing in Markets with Imperfect Information." American Economic Review 71 (3): 393-410.

Taylor, John B. 1993. "Discretion versus Policy Rules in Practice." Carnegie-Rochester Conference Series on Public Policy 39: 195-214. 


\section{This article has been cited by:}

1. BENJAMIN L. COLLIER, ANDREW F. HAUGHWOUT, HOWARD C. KUNREUTHER, ERWANN O. MICHEL-KERJAN. 2019. Firms' Management of Infrequent Shocks. Journal of Money, Credit and Banking . [Crossref]

2. Masayo Shikimi. 2019. Bank loan supply shocks and leverage adjustment. Economic Modelling . [Crossref]

3. Karthik Balakrishnan, Aytekin Ertan. 2019. Bank asset transparency and credit supply. Review of Accounting Studies 24:4, 1359-1391. [Crossref]

4. . Back Matter: Statistical Appendixes and Bibliography 101-135. [Crossref]

5. Eriko Naiki, Yuta Ogane. 2019. Bank soundness and bank lending to new firms during the global financial crisis. Review of Financial Economics . [Crossref]

6. Johannes Bersch, Hans Degryse, Thomas Kick, Ingrid Stein. 2019. The real effects of bank distress: Evidence from bank bailouts in Germany. Journal of Corporate Finance 101521. [Crossref]

7. By Mattia Girotti. 2019. How monetary policy changes bank liability structure and funding cost. Oxford Economic Papers 38. . [Crossref]

8. Salman Tahsin, Timothy J. Yeager. 2019. A residential mortgage bank lending channel during the financial crisis. Journal of Economics and Finance 43:4, 631-656. [Crossref]

9. Pietro Grandi. 2019. Sovereign stress and heterogeneous monetary transmission to bank lending in the euro area. European Economic Review 119, 251-273. [Crossref]

10. Samer Adra, Leonidas Barbopoulos, Anthony Saunders. 2019. The impact of monetary policy on M\&A outcomes. Journal of Corporate Finance 101529. [Crossref]

11. Hans Degryse, Olivier De Jonghe, Sanja Jakovljević, Klaas Mulier, Glenn Schepens. 2019. Identifying credit supply shocks with bank-firm data: Methods and applications. Journal of Financial Intermediation 40, 100813. [Crossref]

12. Florian Heider, Farzad Saidi, Glenn Schepens. 2019. Life below Zero: Bank Lending under Negative Policy Rates. The Review of Financial Studies 32:10, 3728-3761. [Crossref]

13. Christa Hainz, Tatjana Nabokin. 2019. Access to credit and its determinants: A comparison of surveybased measures. Economics of Transition and Institutional Change 27:4, 1031-1067. [Crossref]

14. Davide Furceri, Fabio Mazzola, Pietro Pizzuto. 2019. Asymmetric effects of monetary policy shocks across US states. Papers in Regional Science 98:5, 1861-1891. [Crossref]

15. Gene Ambrocio, Iftekhar Hasan. 2019. What drives discretion in bank lending? Some evidence and a link to private information. Journal of Banking \& Finance 106, 323-340. [Crossref]

16. Itai Agur. 2019. Monetary and macroprudential policy coordination among multiple equilibria. Journal of International Money and Finance 96, 192-209. [Crossref]

17. Isha Agarwal, Rupa Duttagupta, Andrea F. Presbitero. 2019. Commodity Prices and Bank Lending. Economic Inquiry 139. . [Crossref]

18. Henri Fraisse, Mathias Lé, David Thesmar. 2019. The Real Effects of Bank Capital Requirements. Management Science . [Crossref]

19. Paola Morales-Acevedo, Steven Ongena. 2019. FEAR, ANGER, AND CREDIT. ON BANK ROBBERIES AND LOAN CONDITIONS. Economic Inquiry 57. . [Crossref]

20. Xianfeng Jiang, Frank Packer. 2019. Credit ratings of Chinese firms by domestic and global agencies: Assessing the determinants and impact. Journal of Banking \& Finance 105, 178-193. [Crossref] 
21. Philippe Andrade, Christophe Cahn, Henri Fraisse, Jean-Stéphane Mésonnier. 2019. Can the Provision of Long-Term Liquidity Help to Avoid a Credit Crunch? Evidence from the Eurosystem's LTRO. Journal of the European Economic Association 17:4, 1070-1106. [Crossref]

22. Peter Hoffmann, Sam Langfield, Federico Pierobon, Guillaume Vuillemey. 2019. Who Bears Interest Rate Risk?. The Review of Financial Studies 32:8, 2921-2954. [Crossref]

23. Phil Molyneux, Alessio Reghezza, John Thornton, Ru Xie. 2019. Did Negative Interest Rates Improve Bank Lending?. Journal of Financial Services Research 133. . [Crossref]

24. I. E. Shaker. 2019. The Role of the Standardized Approach to Measuring the Counterparty Credit Risk Exposures (Basel III) in Order to Create Conditions for Russia’s Economic Growth. Economics, taxes \& law 12:3, 144-153. [Crossref]

25. Fructuoso Borrallo Egea, Luis Ángel Hierro. 2019. Transmission of monetary policy in the US and EU in times of expansion and crisis. Journal of Policy Modeling 41:4, 763-783. [Crossref]

26. Christoph Basten. 2019. Higher Bank Capital Requirements and Mortgage Pricing: Evidence from the Counter-Cyclical Capital Buffer*. Review of Finance 125. . [Crossref]

27. Sangyup Choi. 2019. Changes in the effects of bank lending shocks and development of public debt markets. Finance Research Letters . [Crossref]

28. Massimiliano Affinito, Giorgio Albareto, Raffaele Santioni. 2019. Purchases of sovereign debt securities by banks during the crisis: The role of balance sheet conditions. Journal of Banking o Finance 105575. [Crossref]

29. Charles Abuka, Ronnie K. Alinda, Camelia Minoiu, José-Luis Peydró, Andrea F. Presbitero. 2019. Monetary policy and bank lending in developing countries: Loan applications, rates, and real effects. Journal of Development Economics 139, 185-202. [Crossref]

30. Paola D'Orazio, Marco Valente. 2019. The role of finance in environmental innovation diffusion: An evolutionary modeling approach. Journal of Economic Behavior \& Organization 162, 417-439. [Crossref]

31. Gabriel Jiménez, Atif Mian, José-Luis Peydró, Jesús Saurina. 2019. The real effects of the bank lending channel. Journal of Monetary Economics . [Crossref]

32. Vasja Sivec, Matjaž Volk. 2019. Bank response to policy-related changes in capital requirements. The Quarterly Review of Economics and Finance . [Crossref]

33. Benjamin L. Collier, Volodymyr O. Babich. 2019. Financing Recovery After Disasters: Explaining Community Credit Market Responses to Severe Events. Journal of Risk and Insurance 86:2, 479-520. [Crossref]

34. Filipa Da Silva Fernandes, Alexandros Kontonikas, Serafeim Tsoukas. 2019. On the Real Effect of Financial Pressure: Evidence From Firm-Level Employment During the Euro-Area Crisis. Oxford Bulletin of Economics and Statistics 81:3, 617-646. [Crossref]

35. David Byrne, Robert Kelly. 2019. Bank asset quality \& monetary policy pass-through. Applied Economics 51:23, 2501-2521. [Crossref]

36. Manthos D. Delis, Iftekhar Hasan, Chris Tsoumas. 2019. The income elasticity of mortgage loan demand. Financial Markets, Institutions \& Instruments 28:2, 115-139. [Crossref]

37. Alexander Karaivanov, Jesús Saurina, Robert M. Townsend. 2019. FAMILY FIRMS, BANK RELATIONSHIPS, AND FINANCIAL CONSTRAINTS: A COMPREHENSIVE SCORE CARD. International Economic Review 60:2, 547-593. [Crossref]

38. Asim Rehman, Sajid M. Chaudhry, Syed Mujahid Hussain. 2019. Transmission of a global financial crisis shock to an emerging economy. International Journal of Finance \& Economics 24:2, 740-760. [Crossref] 
39. Yota D. Deli, Manthos D. Delis, Iftekhar Hasan, Liuling Liu. 2019. Enforcement of banking regulation and the cost of borrowing. Journal of Banking \& Finance 101, 147-160. [Crossref]

40. Filippo Ippolito, Heitor Almeida, Ander Perez Orive, Viral Acharya. 2019. Bank lines of credit as contingent liquidity: Covenant violations and their implications. Journal of Financial Intermediation 100817. [Crossref]

41. Yongqiang Chu, Donghang Zhang, Yijia (Eddie) Zhao. 2019. Bank Capital and Lending: Evidence from Syndicated Loans. Journal of Financial and Quantitative Analysis 54:2, 667-694. [Crossref]

42. Alessandro Barattieri, Maya Eden, Dalibor Stevanovic. 2019. FINANCIAL SECTOR INTERCONNECTEDNESS AND MONETARY POLICY TRANSMISSION. Macroeconomic Dynamics 23:3, 1074-1101. [Crossref]

43. BERNARDO MORAIS, JOSÉ-LUIS PEYDRÓ, JESSICA ROLDÁN-PEÑA, CLAUDIA RUIZORTEGA. 2019. The International Bank Lending Channel of Monetary Policy Rates and QE: Credit Supply, Reach-for-Yield, and Real Effects. The Journal of Finance 74:1, 55-90. [Crossref]

44. Federico Beltrame, Josanco Floreani, Luca Grassetti, Michela Cesarina Mason, Stefano Miani. 2019. Collateral, mutual guarantees and the entrepreneurial orientation of SMEs. Management Decision 57:1, 168-192. [Crossref]

45. . Further Issues in Bank Lending 169-204. [Crossref]

46. Andrada Bilan, Hans Degryse, Kuchulain O’Flynn, Steven Ongena. Application in Banking: Securitization and Global Banking 743-770. [Crossref]

47. Carlo Altavilla, Fabio Canova, Matteo Ciccarelli. 2019. Mending the broken link: Heterogeneous bank lending rates and monetary policy pass-through. Journal of Monetary Economics . [Crossref]

48. Mari L. Robertson. 2019. A QUEST FOR UNFETTERED CREDIT: HOW MONETARY POLICY DRIVES CREDIT RISK TRANSFER OF STRUCTURED FINANCE PRODUCTS. Contemporary Economic Policy 37:1, 138-155. [Crossref]

49. Saibal Ghosh. 2019. Financial inclusion through a public works programme: Does left-wing extremism make a difference?. Development Policy Review 37:1, 19-45. [Crossref]

50. Antonio Afonso, Joana Sousa-Leite. 2019. The Transmission of Unconventional Monetary Policy to Bank Credit Supply: Evidence From the TLTRO. SSRN Electronic Journal . [Crossref]

51. Emmanuel Tweneboah Senzu. 2019. Theoretical Perspective of Dynamic Credit Risk Analysis and Lending Model; Effective to Enterprises of Fragile Economy. SSRN Electronic Journal . [Crossref]

52. Gauti B. Eggertsson, Ragnar Juelsrud, Lawrence H. Summers, Ella Getz Wold. 2019. Negative Nominal Interest Rates and the Bank Lending Channel. SSRN Electronic Journal . [Crossref]

53. Sergio Mayordomo, Omar Rachedi. 2019. The China Syndrome Affects Banks: The Credit Supply Channel of Foreign Import Competition. SSRN Electronic Journal . [Crossref]

54. Prachi Mishra, Nagpurnanand Prabhala, Raghuram G. Rajan. 2019. The Relationship Dilemma: Organizational Culture and the Adoption of Credit Scoring Technology in Indian Banking. SSRN Electronic Journal . [Crossref]

55. Sangyup Choi. 2019. Changes in the Effects of Bank Lending Shocks and Development of Public Debt Markets. SSRN Electronic Journal . [Crossref]

56. Manthos D. Delis, Fulvia Fringuellotti, Steven R. G. Ongena. 2019. Credit and Income Inequality. SSRN Electronic Journal . [Crossref]

57. Olivier Darmouni, Oliver Giesecke, Alexander Rodnyansky. 2019. The Bond Lending Channel of Monetary Policy. SSRN Electronic Journal . [Crossref]

58. Thomas Flanagan. 2019. Stealth Recapitalization and Bank Risk Taking: Evidence from TLTROs. SSRN Electronic Journal . [Crossref] 
59. Carlo Altavilla, Lorenzo Burlon, Mariassunta Giannetti, Sarah Holton. 2019. Is There a Zero Lower Bound? The Effects of Negative Policy Rates on Banks and Firms. SSRN Electronic Journal . [Crossref]

60. Shromona Ganguly. Financing Micro, Small, and Medium Enterprises in Indian Industry 668-680. [Crossref]

61. Linh Nguyen, John O. S. Wilson. 2018. How does credit supply react to a natural disaster? Evidence from the Indian Ocean Tsunami. The European Journal of Finance 1-18. [Crossref]

62. . References 213-221. [Crossref]

63. Mikael Beatriz, Jérôme Coffinet, Théo Nicolas. 2018. Relationship lending and SMEs' funding costs over the cycle: Why diversification of borrowing matters. Journal of Banking \& Finance 105471. [Crossref]

64. Carlos Pérez Montes, Carlos Trucharte Artigas, María Elizabeth Cristófoli, Nadia Lavín San Segundo. 2018. The impact of the IRB approach on the risk weights of European banks. Journal of Financial Stability 39, 147-166. [Crossref]

65. Judit Temesvary. 2018. The transmission of foreign monetary policy shocks into the United States through foreign banks. Journal of Financial Stability 39, 104-124. [Crossref]

66. Elena Cubillas, Nuria Suárez. 2018. Bank market power and lending during the global financial crisis. Journal of International Money and Finance 89, 1-22. [Crossref]

67. Florian Egli, Bjarne Steffen, Tobias S. Schmidt. 2018. A dynamic analysis of financing conditions for renewable energy technologies. Nature Energy 3:12, 1084-1092. [Crossref]

68. Tomas Williams. 2018. Capital Inflows, Sovereign Debt and Bank Lending: Micro-Evidence from an Emerging Market. The Review of Financial Studies 31:12, 4958-4994. [Crossref]

69. Tobias Berg. 2018. Got Rejected? Real Effects of Not Getting a Loan. The Review of Financial Studies 31:12, 4912-4957. [Crossref]

70. Sarah Holton, Costanza Rodriguez d'Acri. 2018. Interest rate pass-through since the euro area crisis. Journal of Banking \& Finance 96, 277-291. [Crossref]

71. Alexander Popov, Jörg Rocholl. 2018. Do credit shocks affect labor demand? Evidence for employment and wages during the financial crisis. Journal of Financial Intermediation 36, 16-27. [Crossref]

72. Pierluigi Balduzzi, Emanuele Brancati, Fabio Schiantarelli. 2018. Financial markets, banks' cost of funding, and firms' decisions: Lessons from two crises. Journal of Financial Intermediation 36, 1-15. [Crossref]

73. Hans Degryse, Kent Matthews, Tianshu Zhao. 2018. SMEs and access to bank credit: Evidence on the regional propagation of the financial crisis in the UK. Journal of Financial Stability 38, 53-70. [Crossref]

74. Sebastian Doerr, Mehdi Raissi, Anke Weber. 2018. Credit-supply shocks and firm productivity in Italy. Journal of International Money and Finance 87, 155-171. [Crossref]

75. Nicola Gennaioli, Alberto Martin, Stefano Rossi. 2018. Banks, government Bonds, and Default: What do the data Say?. Journal of Monetary Economics 98, 98-113. [Crossref]

76. DIANA BONFIM, CARLA SOARES. 2018. The Risk-Taking Channel of Monetary Policy: Exploring All Avenues. Journal of Money, Credit and Banking 50:7, 1507-1541. [Crossref]

77. Alin Andries,, Nicu Marcu, Florin Oprea, Mihaela Tofan. 2018. Financial Infrastructure and Access to Finance for European SMEs. Sustainability 10:10, 3400. [Crossref]

78. Besma Hamdi, Sami Hammami. 2018. The Crisis of Sovereign Debt in the Euro Zone: Effect on the Banking Sector. Journal of the Knowledge Economy 9:3, 822-832. [Crossref] 
79. Alfred V Guender. 2018. Credit prices vs. credit quantities as predictors of economic activity in Europe: Which tell a better story?. Journal of Macroeconomics 57, 380-399. [Crossref]

80. Vicente Cuñat, Dragana Cvijanović, Kathy Yuan. 2018. Within-Bank Spillovers of Real Estate Shocks. The Review of Corporate Finance Studies 7:2, 157-193. [Crossref]

81. Andrew Sutherland. 2018. Does credit reporting lead to a decline in relationship lending? Evidence from information sharing technology. Journal of Accounting and Economics 66:1, 123-141. [Crossref]

82. Henri Fraisse, Johan Hombert, Mathias Lé. 2018. The competitive effect of a bank megamerger on credit supply. Journal of Banking \& Finance 93, 151-161. [Crossref]

83. Robert Kurtzman, Stephan Luck, Tom Zimmermann. 2018. Did QE lead banks to relax their lending standards? Evidence from the Federal Reserve's LSAPs. Journal of Banking \& Finance 105403. [Crossref]

84. Giacomo Rodano, Nicolas Serrano-Velarde, Emanuele Tarantino. 2018. Lending Standards over the Credit Cycle. The Review of Financial Studies 31:8, 2943-2982. [Crossref]

85. Tümer Kapan, Camelia Minoiu. 2018. Balance sheet strength and bank lending: Evidence from the global financial crisis. Journal of Banking \& Finance 92, 35-50. [Crossref]

86. Leonardo Gambacorta, Hyun Song Shin. 2018. Why bank capital matters for monetary policy. Journal of Financial Intermediation 35, 17-29. [Crossref]

87. Steven Ongena, Günseli Tümer-Alkan, Natalja von Westernhagen. 2018. Do Exposures to Sagging Real Estate, Subprime, or Conduits Abroad Lead to Contraction and Flight to Quality in Bank Lending at Home?*. Review of Finance 22:4, 1335-1373. [Crossref]

88. Sumon Kumar Bhaumik, Oluwarotimi Owolabi, Sarmistha Pal. 2018. Private information, institutional distance, and the failure of cross-border acquisitions: Evidence from the banking sector in Central and Eastern Europe. Journal of World Business 53:4, 504-513. [Crossref]

89. Marcello Bofondi, Luisa Carpinelli, Enrico Sette. 2018. Credit Supply During a Sovereign Debt Crisis. Journal of the European Economic Association 16:3, 696-729. [Crossref]

90. Samuel Bentolila, Marcel Jansen, Gabriel Jiménez. 2018. When Credit Dries Up: Job Losses in the Great Recession. Journal of the European Economic Association 16:3, 650-695. [Crossref]

91. Mihye Lee. 2018. Do Firm and Bank Level Characteristics Matter for Lending to Firms during the Financial Crisis?. Journal of Industrial Distribution \& Business 9:5, 37-46. [Crossref]

92. Saibal Ghosh. 2018. Governance reforms and performance of MENA banks: Are disclosures effective?. Global Finance Journal 36, 78-95. [Crossref]

93. Judit Temesvary, Steven Ongena, Ann L. Owen. 2018. A global lending channel unplugged? Does U.S. monetary policy affect cross-border and affiliate lending by global U.S. banks?. Journal of International Economics 112, 50-69. [Crossref]

94. Filippo Ippolito, Ali K. Ozdagli, Ander Perez-Orive. 2018. The transmission of monetary policy through bank lending: The floating rate channel. Journal of Monetary Economics 95, 49-71. [Crossref]

95. Ali Awdeh. 2018. Long-run and Short-run Monetary Policy Transmission Channels in Lebanon. Review of Middle East Economics and Finance 14:1. . [Crossref]

96. José María Liberti, Jason Sturgess. 2018. The Anatomy of a Credit Supply Shock: Evidence from an Internal Credit Market. Journal of Financial and Quantitative Analysis 53:2, 547-579. [Crossref]

97. Tullio Jappelli, Annalisa Scognamiglio. 2018. Interest rate changes, mortgages, and consumption: evidence from Italy. Economic Policy 33:94, 183-224. [Crossref]

98. María Cantero Sáiz, Sergio Sanfilippo Azofra, Begoña Torre Olmo, Carlos López Gutiérrez. 2018. A new approach to the analysis of monetary policy transmission through bank capital. Finance Research Letters 24, 95-104. [Crossref] 
99. Juliane Gerstenberger. 2018. Impaired capital reallocation in a low-interest rate environment. ORDO 68:1, 65-88. [Crossref]

100. Jaakko Sääskilahti. 2018. Retail Bank Interest Margins in Low Interest Rate Environments. Journal of Financial Services Research 53:1, 37-68. [Crossref]

101. Sumit Agarwal, Souphala Chomsisengphet, Neale Mahoney, Johannes Stroebel. 2018. Do Banks Pass through Credit Expansions to Consumers Who want to Borrow?*. The Quarterly Journal of Economics 133:1, 129-190. [Crossref]

102. Beatriz Fernández Muñiz, José Manuel Montes Peón, Camilo José Vázquez Ordás. Assessing and Measuring Banking Culture 363-387. [Crossref]

103. Shaofang Li. Introduction 1-8. [Crossref]

104. Shaofang Li. Quality of Bank Capital and Bank Lending Behaviour During the Global Financial Crisis 69-104. [Crossref]

105. Nadja Dwenger, Frank M. Fossen, Martin Simmler. 2018. Firms' financial and real responses to credit supply shocks: Evidence from firm-bank relationships in Germany. Journal of Financial Intermediation 100773. [Crossref]

106. Thorsten Beck, Hans Degryse, Ralph De Haas, Neeltje van Horen. 2018. When arm's length is too far: Relationship banking over the credit cycle. Journal of Financial Economics 127:1, 174-196. [Crossref]

107. Adrien Amzallag, Alessandro Calza, Dimitris Georgarakos, Jooo Sousa. 2018. Monetary Policy Transmission to Mortgages in a Negative Interest Rate Environment. SSRN Electronic Journal . [Crossref]

108. Yongqiang Chu, Daxuan Zhao. 2018. Access to Public Capital Markets and Bank Lending. SSRN Electronic Journal . [Crossref]

109. Piotr Denderski, Wojtek Paczos. 2018. Foreign Banks and the Bank Lending Channel. SSRN Electronic Journal . [Crossref]

110. Sebastian Doerr, Stefan Gissler, Jose-Luis Peydro, Hans-Joachim Voth. 2018. From Finance to Extremism: The Real Effects of Germany's 1931 Banking Crisis. SSRN Electronic Journal . [Crossref]

111. Gabriel Jimenez, Enrique Moral-Benito, Raquel Vegas. 2018. Bank Lending Standards Over the Cycle: The Role of Firmss Productivity and Credit Risk. SSRN Electronic Journal . [Crossref]

112. Martina Jasova, Caterina Mendicino, Dominik Supera. 2018. Rollover Risk and Bank Lending Behavior: Evidence From Unconventional Central Bank Liquidity. SSRN Electronic Journal . [Crossref]

113. Pietro Grandi. 2018. Sovereign Risk and Cross-Country Heterogeneity in the Transmission of Monetary Policy to Bank Lending in the Euro Area. SSRN Electronic Journal . [Crossref]

114. Adonis Antoniades. 2018. Uneven Recovery: Mortgage Credit and the Concentration Channel. SSRN Electronic Journal . [Crossref]

115. Robert A. Connolly, Tobias Muhlhofer. 2018. Leverage Cycles in a Mature Asset Class: New Evidence From a Natural Laboratory. SSRN Electronic Journal . [Crossref]

116. Alexander Rad, Peter Öhman, Darush Yazdanfar. 2018. Loan Officers' Information Focus in SME Loan Assessment: A Case Study. SSRN Electronic Journal . [Crossref]

117. Co-Pierre Georg, Diane Pierret, Sascha Steffen. 2018. Similar Investors. SSRN Electronic Journal . [Crossref]

118. Michael Sigmund, Sophia Döme. 2018. The Impact of Unconventional Monetary Policy on Major European Banks' Interest Spreads. SSRN Electronic Journal . [Crossref] 
119. Patrick Behr, Lars Norden, Raquel F. Oliveira. 2018. The Real Effects of Bank-Firm Relationships. SSRN Electronic Journal . [Crossref]

120. Allen N. Berger, Donghang Zhang, Yijia Zhao. 2018. Bank Specialness, Credit Lines, and Loan Structure. SSRN Electronic Journal . [Crossref]

121. Pablo Slutzky, Mauricio Villamizar-Villegas, Tomas Williams. 2018. Drug Money and Firms: The Unintended Consequences of Anti-Money Laundering Policies. SSRN Electronic Journal . [Crossref]

122. Hitoshi Inoue, Kiyotaka Nakashima, Koji Takahashi. 2018. The Emergence of a Parallel World: The Misperception Problem for Bank Balance Sheet Risk and Lending Behavior. SSRN Electronic Journal . [Crossref]

123. Gareth Anderson, Saleem Bahaj, Matthieu Chavaz, Angus Foulis, Gabor Pinter. 2018. Lending Relationships and the Collateral Channel. SSRN Electronic Journal . [Crossref]

124. Philip Molyneux, Alessio Reghezza, John Thornton, Ru Xie. 2018. Did Negative Interest Rates Improve Bank Lending?. SSRN Electronic Journal . [Crossref]

125. Gazi Kara, Youngsuk Yook. 2018. Policy Uncertainty and Bank Mortgage Credit. SSRN Electronic Journal . [Crossref]

126. Mickael B\&eacute;atriz, Jerome Coffinet, Theo Nicolas. 2018. Relationship Lending and SMEs' Funding Costs Over the Cycle: Why Diversification of Borrowing Matters. SSRN Electronic Journal . [Crossref]

127. Yavuz Arslan, Ahmet Degerli, Gazi Kabas. 2018. Unintended Consequences of Unemployment Insurance Benefits: The Role of Banks. SSRN Electronic Journal . [Crossref]

128. Saibal Ghosh. 2017. Banking and credit extension: does religious diversity matter?. International Journal of Social Economics 44:12, 2287-2301. [Crossref]

129. Michael Demoussis, Konstantinos Drakos, Nicholas Giannakopoulos. 2017. The impact of sovereign ratings on euro zone SMEs' credit rationing. Journal of Economic Studies 44:5, 745-764. [Crossref]

130. Juan S. Mora-Sanguinetti, Marta Martínez-Matute, Miguel García-Posada. 2017. Credit, crisis and contract enforcement: evidence from the Spanish loan market. European Journal of Law and Economics 44:2, 361-383. [Crossref]

131. Anna Samarina, Lu Zhang, Dirk Bezemer. 2017. Credit cycle coherence in the eurozone: Was there a euro effect?. Journal of International Money and Finance 77, 77-98. [Crossref]

132. Burkhard Raunig, Johann Scharler, Friedrich Sindermann. 2017. Do Banks Lend Less in Uncertain Times?. Economica 84:336, 682-711. [Crossref]

133. Ola Melander, Maria Sandström, Erik von Schedvin. 2017. The effect of cash flow on investment: an empirical test of the balance sheet theory. Empirical Economics 53:2, 695-716. [Crossref]

134. Yota D. Deli, Iftekhar Hasan. 2017. Real effects of bank capital regulations: Global evidence. Journal of Banking \& Finance 82, 217-228. [Crossref]

135. Awatef Louhichi, Younes Boujelbene. 2017. Bank capital, lending and financing behaviour of dual banking systems. Journal of Multinational Financial Management 41, 61-79. [Crossref]

136. Gabriel Jiménez, Steven Ongena, José-Luis Peydró, Jesús Saurina. 2017. "In the Short Run Blasé, In the Long Run Risqué”. Schmalenbach Business Review 18:3, 181-226. [Crossref]

137. Hirofumi Fukuyama, Roman Matousek. 2017. Modelling bank performance: A network DEA approach. European Journal of Operational Research 259:2, 721-732. [Crossref]

138. S. Avouyi-Dovi, G. Horny, P. Sevestre. 2017. The stability of short-term interest rates pass-through in the euro area during the financial market and sovereign debt crises. Journal of Banking \& Finance 79, 74-94. [Crossref] 
139. Matthew Osborne, Ana-Maria Fuertes, Alistair Milne. 2017. In good times and in bad: Bank capital ratios and lending rates. International Review of Financial Analysis 51, 102-112. [Crossref]

140. Yusuf Soner Baskaya, Julian di Giovanni, Şebnem Kalemli-Özcan, José-Luis Peydro, Mehmet Fatih Ulu. 2017. Capital flows and the international credit channel. Journal of International Economics 108, S15-S22. [Crossref]

141. Ugo Albertazzi, Margherita Bottero, Gabriele Sene. 2017. Information externalities in the credit market and the spell of credit rationing. Journal of Financial Intermediation 30, 61-70. [Crossref]

142. Steven Ongena, Ibolya Schindele, Dzsamila Vonnák. 2017. Monetáris politika és a bankok hitelkínálata. Vállalati adatokon alapuló elemzés. Közgazdasági Szemle 64:3, 217-237. [Crossref]

143. Patrycja Klusak, Rasha Alsakka, Owain ap Gwilym. 2017. Does the disclosure of unsolicited sovereign rating status affect bank ratings?. The British Accounting Review 49:2, 194-210. [Crossref]

144. Manthos D. Delis, Sotirios Kokas, Steven Ongena. 2017. Bank Market Power and Firm Performance*. Review of Finance 21:1, 299-326. [Crossref]

145. Joris Tielens, Jan Van Hove. 2017. The Amiti-Weinstein estimator: An equivalence result. Economics Letters 151, 19-22. [Crossref]

146. Fabrice Collard, Harris Dellas, Behzad Diba, Olivier Loisel. 2017. Optimal Monetary and Prudential Policies. American Economic Journal: Macroeconomics 9:1, 40-87. [Abstract] [View PDF article] [PDF with links]

147. Paola Brighi, Valeria Venturelli. Demand and Supply Determinants of Credit Availability: Evidence from the Current Credit Crisis for European SMEs 41-70. [Crossref]

148. Yongqiang Chu, Donghang Zhang, Yijia Zhao. 2017. Bank Capital and Lending: Evidence from Syndicated Loans. SSRN Electronic Journal . [Crossref]

149. Jonatan Groba, Pedro Serrano. 2017. Foreign Monetary Policy and Firms' Default Risk. SSRN Electronic Journal . [Crossref]

150. Aytekin Ertan, Stephen A. Karolyi. 2017. Credit Supply and Contracting on Hard Information in Debt Markets. SSRN Electronic Journal . [Crossref]

151. Viral V. Acharya, Heitor Almeida, Filippo Ippolito, Ander Perez-Orive. 2017. Credit Lines and the Liquidity Insurance Channel. SSRN Electronic Journal . [Crossref]

152. Rainer F. H. Haselmann, Vikrant Vig. 2017. Rent-Seeking in Elite Networks. SSRN Electronic Journal . [Crossref]

153. Luisa Carpinelli, Matteo Crosignani. 2017. The Effect of Central Bank Liquidity Injections on Bank Credit Supply. SSRN Electronic Journal . [Crossref]

154. Lu Zhang, Arzu Uluc. 2017. Did Pre-Crisis Mortgage Lending Limit Post-Crisis Corporate Lending? Evidence from UK Bank Balance Sheets. SSRN Electronic Journal . [Crossref]

155. Jose-Luis Peydro, Andrea Polo, Enrico Sette. 2017. Monetary Policy at Work: Security and Credit Application Registers Evidence. SSRN Electronic Journal . [Crossref]

156. Karthik Balakrishnan, Aytekin Ertan. 2017. Mandatory Bank Disclosures and Credit Access. SSRN Electronic Journal . [Crossref]

157. Piergiorgio Alessandri, Margherita Bottero. 2017. Bank Lending in Uncertain Times. SSRN Electronic Journal . [Crossref]

158. Francesco Bripi. 2017. Services Trade and Credit Frictions: Evidence from Matched Bank-Firm Data. SSRN Electronic Journal . [Crossref]

159. Robert J. Kurtzman, Stephan Luck, Tom Zimmermann. 2017. Did QE Lead to Lax Bank Lending Standards? Evidence from the Federal Reserve's LSAPs. SSRN Electronic Journal . [Crossref] 
160. Mascia Bedendo, Emilia Garcia-Appendini, Linus Siming. 2017. Cultural Preferences and the Choice between Formal and Informal Financing. SSRN Electronic Journal . [Crossref]

161. Kiyotaka Nakashima, Masahiko Shibamoto, Koji Takahashi. 2017. Risk-Taking Channel of Unconventional Monetary Policies in Bank Lending. SSRN Electronic Journal . [Crossref]

162. Saleem Bahaj, Frederic Malherbe. 2017. A Positive Analysis of Bank Behavior Under Capital Requirements. SSRN Electronic Journal . [Crossref]

163. Sebastian Dörr, Mehdi Raissi, Anke Weber. 2017. Credit-Supply Shocks and Firm Productivity in Italy. IMF Working Papers 17:67, 1. [Crossref]

164. Ivo Krznar, Troy Matheson. 2017. Towards Macroprudential Stress Testing: Incorporating MacroFeedback Effects. IMF Working Papers 17:149, 1. [Crossref]

165. Mercè Sala-Rios, Teresa Torres-Solé, Mariona Farré-Perdiguer. 2016. Credit and business cycles' relationship: evidence from Spain. Portuguese Economic Journal 15:3, 149-171. [Crossref]

166. Claudia Pigini, Andrea F. Presbitero, Alberto Zazzaro. 2016. State dependence in access to credit. Journal of Financial Stability 27, 17-34. [Crossref]

167. Daisuke Tsuruta. 2016. No lending relationships and liquidity management of small businesses during a financial shock. Journal of the Japanese and International Economies 42, 31-46. [Crossref]

168. Zuzana Fungáčová, Riikka Nuutilainen, Laurent Weill. 2016. Reserve requirements and the bank lending channel in China. Journal of Macroeconomics 50, 37-50. [Crossref]

169. Adonis Antoniades. 2016. Liquidity Risk and the Credit Crunch of 2007-2008: Evidence from MicroLevel Data on Mortgage Loan Applications. Journal of Financial and Quantitative Analysis 51:6, 1795-1822. [Crossref]

170. Ken B. Cyree, Mark D. Griffiths, Drew B. Winters. 2016. U.S. BANK LENDING ACTIVITY IN THE POSTCRISIS WORLD. Journal of Financial Research 39:4, 389-410. [Crossref]

171. Luis Garicano, Claudia Steinwender. 2016. Survive Another Day: Using Changes in the Composition of Investments to Measure the Cost of Credit Constraints. Review of Economics and Statistics 98:5, 913-924. [Crossref]

172. Miguel García-Posada, Marcos Marchetti. 2016. The bank lending channel of unconventional monetary policy: The impact of the VLTROs on credit supply in Spain. Economic Modelling 58, 427-441. [Crossref]

173. José-Luis Peydró. 2016. Macroprudential Policy and Credit Supply. Swiss Journal of Economics and Statistics 152:4, 305-318. [Crossref]

174. Filippo Ippolito, José-Luis Peydró, Andrea Polo, Enrico Sette. 2016. Double bank runs and liquidity risk management. Journal of Financial Economics 122:1, 135-154. [Crossref]

175. Bo Becker, Jens Josephson. 2016. Insolvency Resolution and the Missing High-Yield Bond Markets. Review of Financial Studies 29:10, 2814-2849. [Crossref]

176. Patrick Bolton, Xavier Freixas, Leonardo Gambacorta, Paolo Emilio Mistrulli. 2016. Relationship and Transaction Lending in a Crisis. The Review of Financial Studies 29:10, 2643-2676. [Crossref]

177. Sebnem Kalemli-Ozcan, Herman Kamil, Carolina Villegas-Sanchez. 2016. What Hinders Investment in the Aftermath of Financial Crises: Insolvent Firms or Illiquid Banks?. Review of Economics and Statistics 98:4, 756-769. [Crossref]

178. Magda Kandil. 2016. Domestic policies and external spillovers. International Journal of Development Issues 15:3, 254-293. [Crossref]

179. Puriya Abbassi, Rajkamal Iyer, José-Luis Peydró, Francesc R. Tous. 2016. Securities trading by banks and credit supply: Micro-evidence from the crisis. Journal of Financial Economics 121:3, 569-594. [Crossref] 
180. Jaakko Sääskilahti. 2016. Local bank competition and small business lending after the onset of the financial crisis. Journal of Banking \& Finance 69, 37-51. [Crossref]

181. Søren Hove Ravn. 2016. Endogenous credit standards and aggregate fluctuations. Journal of Economic Dynamics and Control 69, 89-111. [Crossref]

182. Raul Ibarra. 2016. How important is the credit channel in the transmission of monetary policy in Mexico?. Applied Economics 48:36, 3462-3484. [Crossref]

183. Josh Ryan-Collins, Richard A. Werner, Jennifer Castle. 2016. A half-century diversion of monetary policy? An empirical horse-race to identify the UK variable most likely to deliver the desired nominal GDP growth rate. Journal of International Financial Markets, Institutions and Money 43, 158-176. [Crossref]

184. Hélène Rey. 2016. International Channels of Transmission of Monetary Policy and the Mundellian Trilemma. IMF Economic Review 64:1, 6-35. [Crossref]

185. Karolin Kirschenmann. 2016. Credit rationing in small firm-bank relationships. Journal of Financial Intermediation 26, 68-99. [Crossref]

186. Giovanni Dell'Ariccia, Deniz Igan, Luc Laeven, Hui Tong. 2016. Credit booms and macrofinancial stability. Economic Policy 31:86, 299-355. [Crossref]

187. Kiyotaka Nakashima. 2016. An econometric evaluation of bank recapitalization programs with bankand loan-level data. Journal of Banking \& Finance 63, 1-24. [Crossref]

188. SANTIAGO CARBÓ-VALVERDE, FRANCISCO RODRÍGUEZ-FERNÁNDEZ, GREGORY F. UDELL. 2016. Trade Credit, the Financial Crisis, and SME Access to Finance. Journal of Money, Credit and Banking 48:1, 113-143. [Crossref]

189. Sanja Jakovljević, Hans Degryse, Steven Ongena. Monetary Transmission and Regulatory Impacts: Empirical Evidence from the Post-Crisis Banking Literature 18-41. [Crossref]

190. Katarzyna Sum. Banking Regulation and Bank Lending in the EU 209-250. [Crossref]

191. Daniel Blaseg, Michael Koetter. Crowdfunding and Bank Stress 17-54. [Crossref]

192. . Further Issues in Bank Lending 169-204. [Crossref]

193. . References 243-254. [Crossref]

194. Emilia Bonaccorsi di Patti, Enrico Sette. 2016. Did the securitization market freeze affect bank lending during the financial crisis? Evidence from a credit register. Journal of Financial Intermediation 25, 54-76. [Crossref]

195. Anjan V. Thakor. 2016. The highs and the lows: A theory of credit risk assessment and pricing through the business cycle. Journal of Financial Intermediation 25, 1-29. [Crossref]

196. Rients Galema, Michael Koetter. European Bank Efficiency and Performance: The Effects of Supranational Versus National Bank Supervision 257-292. [Crossref]

197. Mintra Dwarkasing, Narly Dwarkasing, Steven Ongena. The Bank Lending Channel of Monetary Policy: A Review of the Literature and an Agenda for Future Research 383-407. [Crossref]

198. Dirk Bezemer, Maria Grydaki, Lu Zhang. 2016. MORE MORTGAGES, LOWER GROWTH?. Economic Inquiry 54:1, 652-674. [Crossref]

199. Linh Nguyen, John O. S. Wilson. 2016. How Does Bank Lending React to a Catastrophic Weather Event? Evidence from the Indian Ocean Tsunami. SSRN Electronic Journal . [Crossref]

200. Saleem Bahaj, Jonathan Bridges, Frederic Malherbe, Cian O'Neill. 2016. What Determines How Banks Respond to Changes in Capital Requirements?. SSRN Electronic Journal . [Crossref]

201. Mattia Girotti. 2016. How Monetary Policy Changes Bank Liability Structure and Funding Cost. SSRN Electronic Journal . [Crossref] 
202. Henri Fraisse, Johan Hombert, Mathias LL. 2016. The Competitive Effect of a Bank Megamerger on Credit Supply. SSRN Electronic Journal . [Crossref]

203. Tore Ellingsen, Tor Jacobson. 2016. Trade Credit: Contract-Level Evidence Contradicts Current Theories. SSRN Electronic Journal . [Crossref]

204. Christoph Bertsch, Isaiah Hull, Xin Zhang. 2016. Fed Liftoff and Subprime Loan Interest Rates: Evidence From the Peer-to-Peer Lending Market. SSRN Electronic Journal . [Crossref]

205. Massimiliano Affinito, Giorgio Albareto, Raffaele Santioni. 2016. Purchases of Sovereign Debt Securities by Italian Banks During the Crisis: The Role of Balance-Sheet Conditions. SSRN Electronic Journal . [Crossref]

206. Markus Merz, Jan Riepe. 2016. Access to Banking and Its Value in Developed Countries: Evidence from the U.S. Marijuana Industry. SSRN Electronic Journal . [Crossref]

207. Juan S. Mora-Sanguinetti, Marta Martinez-Matute. 2016. Credit, Crisis and Contract Enforcement: Evidence from the Spanish Loan Market. SSRN Electronic Journal . [Crossref]

208. Zsolt Darvas, Dirk Schoenmaker, Nicolas Veron. 2016. Reforms to the European Union Financial Supervisory and Regulatory Architecture and Their Implications for Asia. SSRN Electronic Journal . [Crossref]

209. Ugo Albertazzi. 2016. The Bank Lending Channel of Conventional and Unconventional Monetary Policy. SSRN Electronic Journal . [Crossref]

210. Viral V. Acharya, Heitor Almeida, Filippo Ippolito, Ander Perez-Orive. 2016. Bank Lines of Credit as Contingent Liquidity: Covenant Violations and Their Implications. SSRN Electronic Journal . [Crossref]

211. Tobias Adrian, Daniel Covitz, Nellie Liang. 2015. Financial Stability Monitoring. Annual Review of Financial Economics 7:1, 357-395. [Crossref]

212. Maria Iosifidi, Sotirios Kokas. 2015. Who lends to riskier and lower-profitability firms? Evidence from the syndicated loan market. Journal of Banking \& Finance 61, S14-S21. [Crossref]

213. Christoffer Koch. 2015. Deposit interest rate ceilings as credit supply shifters: Bank level evidence on the effects of Regulation Q. Journal of Banking \& Finance 61, 316-326. [Crossref]

214. Rudiger Ahrend, Antoine Goujard. 2015. Global banking, global crises? The role of the bank balance-sheet channel for the transmission of financial crises. European Economic Review 80, 253-279. [Crossref]

215. Neil Bhutta. 2015. The ins and outs of mortgage debt during the housing boom and bust. Journal of Monetary Economics 76, 284-298. [Crossref]

216. Steven Ongena, José-Luis Peydró, Neeltje van Horen. 2015. Shocks Abroad, Pain at Home? BankFirm-Level Evidence on the International Transmission of Financial Shocks. IMF Economic Review 63:4, 698-750. [Crossref]

217. Matteo Ciccarelli, Angela Maddaloni, José-Luis Peydró. 2015. Trusting the bankers: A new look at the credit channel of monetary policy. Review of Economic Dynamics 18:4, 979-1002. [Crossref]

218. MARK CARLSON, JONATHAN D. ROSE. 2015. Credit Availability and the Collapse of the Banking Sector in the 1930s. Journal of Money, Credit and Banking 47:7, 1239-1271. [Crossref]

219. Alexander Popov, Neeltje Van Horen. 2015. Exporting Sovereign Stress: Evidence from Syndicated Bank Lending during the Euro Area Sovereign Debt Crisis*. Review of Finance 19:5, 1825-1866. [Crossref]

220. Gerhard Illing. 2015. Unkonventionelle Geldpolitik - kein Paradigmenwechsel. Perspektiven der Wirtschaftspolitik 16:2, 127-150. [Crossref]

221. 2015. Journal of Banking and Financial Economics 1:3. . [Crossref] 
222. Giovanni Favara, Jean Imbs. 2015. Credit Supply and the Price of Housing. American Economic Review 105:3, 958-992. [Abstract] [View PDF article] [PDF with links]

223. Vasso Ioannidou, Steven Ongena, José-Luis Peydró. 2015. Monetary Policy, Risk-Taking, and Pricing: Evidence from a Quasi-Natural Experiment*. Review of Finance 19:1, 95-144. [Crossref]

224. Moazzam Farooq, Sajjad Zaheer. 2015. Are Islamic Banks More Resilient During Financial Panics?. Pacific Economic Review 20:1, 101-124. [Crossref]

225. Kaoru Hosono, Daisuke Miyakawa. Bank Lending and Firm Activities: Overcoming Identification Problems 237-260. [Crossref]

226. Marko Košak, Shaofang Li, Igor Lončarski, Matej Marinč. 2015. Quality of bank capital and bank lending behavior during the global financial crisis. International Review of Financial Analysis 37, 168-183. [Crossref]

227. D. Paravisini, V. Rappoport, P. Schnabl, D. Wolfenzon. 2015. Dissecting the Effect of Credit Supply on Trade: Evidence from Matched Credit-Export Data. The Review of Economic Studies 82:1, 333-359. [Crossref]

228. Manthos D. Delis, Sotirios Kokas, Steven Ongena. 2015. Bank Market Power and Firm Performance. SSRN Electronic Journal . [Crossref]

229. Maria Iosifidi, Sotirios Kokas. 2015. Who Lends to Riskier and Lower-Profitability Firms? Evidence from the Syndicated Loan Market. SSRN Electronic Journal . [Crossref]

230. Filippo Ippolito, Jose-Luis Peydro, Andrea Polo, Enrico Sette. 2015. Double Bank Runs and Liquidity Risk Management. SSRN Electronic Journal . [Crossref]

231. Puriya Abbassi, Rajkamal Iyer, Jose-Luis Peydro, Francesc Rodriguez Tous. 2015. Securities Trading by Banks and Credit Supply: Micro-Evidence. SSRN Electronic Journal . [Crossref]

232. Philippe Andrade, Christophe Cahn, Henri Fraisse, Jean-Sttphane MMsonnier. 2015. Can the Provision of Long-Term Liquidity Help to Avoid a Credit Crunch? Evidence from the Eurosystem's LTROs. SSRN Electronic Journal . [Crossref]

233. Mattia Girotti. 2015. How Monetary Policy Changes Bank Liability Structure and Funding Cost. SSRN Electronic Journal . [Crossref]

234. Natalya Martynova. 2015. Effect of Bank Capital Requirements on Economic Growth: A Survey. SSRN Electronic Journal . [Crossref]

235. Bo Becker, Marieke Bos, Kasper Roszbach. 2015. Bad Times, Good Credit. SSRN Electronic Journal . [Crossref]

236. Miguel Garcia-Posada, Marco Marchetti. 2015. The Bank Lending Channel of Unconventional Monetary Policy: The Impact of the VILTROs on Credit Supply in Spain. SSRN Electronic Journal . [Crossref]

237. Francois Koulischer. 2015. Asymmetric Shocks in a Currency Union: The Role of Central Bank Collateral Policy. SSRN Electronic Journal . [Crossref]

238. Andrea Nobili, Andrea Orame. 2015. Estimating the Effects of a Credit Supply Restriction: Is There a Bias in the Bank Lending Survey?. SSRN Electronic Journal . [Crossref]

239. Anjan V. Thakor. 2015. The Highs and the Lows: A Theory of Credit Risk Assessment and Pricing Through the Business Cycle. SSRN Electronic Journal . [Crossref]

240. Andrew Sutherland. 2015. The Economic Consequences of Borrower Information Sharing: Relationship Dynamics and Investment. SSRN Electronic Journal . [Crossref]

241. Lisa Cycon, Michael Koetter. 2015. Monetary Policy Under the Microscope: Intra-Bank Transmission of Asset Purchase Programs of the ECB. SSRN Electronic Journal . [Crossref] 
242. Nadja Dwenger, Frank M. Fossen, Martin Simmler. 2015. From Financial to Real Economic Crisis: Evidence from Individual Firm-Bank Relationships in Germany. SSRN Electronic Journal . [Crossref]

243. Giacomo Rodano, Nicolas Andre Benigno Serrano-Velarde, Emanuele Tarantino. 2015. Lending Standards Over the Credit Cycle. SSRN Electronic Journal . [Crossref]

244. Marco Di Maggio, Amir Kermani, Christopher Palmer. 2015. Unconventional Monetary Policy and the Allocation of Credit. SSRN Electronic Journal . [Crossref]

245. Allen N. Berger, Tanakorn Makaew, Rima Turk-Ariss. 2015. Who Pays for Financial Crises? Price and Quantity Rationing of Different Borrowers by Domestic and Foreign Banks. SSRN Electronic Journal . [Crossref]

246. Moazzam Farooq, Sajjad Zaheer. 2015. Are Islamic Banks More Resilient during Financial Panics?. IMF Working Papers 15:41, 1. [Crossref]

247. Charles Abuka, Ronnie Alinda, Camelia Minoiu, José-Luis Peydró, Andrea Presbitero. 2015. Monetary Policy in a Developing Country: Loan Applications and Real Effects. IMF Working Papers 15:270, 1. [Crossref]

248. Zuzana Fungáčová, Laura Solanko, Laurent Weill. 2014. Does competition influence the bank lending channel in the euro area?. Journal of Banking \& Finance 49, 356-366. [Crossref]

249. François Koulischer, Daan Struyven. 2014. Central bank liquidity provision and collateral quality. Journal of Banking \& Finance 49, 113-130. [Crossref]

250. Robert E. Krainer. 2014. Monetary policy and bank lending in the Euro area: Is there a stock market channel or an interest rate channel?. Journal of International Money and Finance 49, 283-298. [Crossref]

251. Giovanni Ferri, Panu Kalmi, Eeva Kerola. 2014. Does bank ownership affect lending behavior? Evidence from the Euro area. Journal of Banking \& Finance 48, 194-209. [Crossref]

252. Vikram Jambulapati, Joanna Stavins. 2014. Credit CARD Act of 2009: What did banks do?. Journal of Banking \& Finance 46, 21-30. [Crossref]

253. Ozlem Akin, José García Montalvo, Jaume García Villar, José-Luis Peydró, Josep Maria Raya. 2014. The real estate and credit bubble: evidence from Spain. SERIEs 5:2-3, 223-243. [Crossref]

254. Ignacio Hernando, Ernesto Villanueva. 2014. The recent slowdown in bank lending in Spain: are supply-side factors relevant?. SERIEs 5:2-3, 245-285. [Crossref]

255. Eddie Casey, Conor M. O'Toole. 2014. Bank lending constraints, trade credit and alternative financing during the financial crisis: Evidence from European SMEs. Journal of Corporate Finance 27, 173-193. [Crossref]

256. Ralf R. Meisenzahl. 2014. Verifying the state of financing constraints: Evidence from U.S. business credit contracts. Journal of Economic Dynamics and Control 43, 58-77. [Crossref]

257. Leonardo Gambacorta, Michela Scatigna, Jing Yang. 2014. Diversification and bank profitability: a nonlinear approach. Applied Economics Letters 21:6, 438-441. [Crossref]

258. Valeriya Dinger, Sven Steinkamp, Frank Westermann. 2014. The Tragedy of the Commons and Inflation Bias in the Euro Area. Open Economies Review 25:1, 71-91. [Crossref]

259. ANDREA F. PRESBITERO, GREGORY F. UDELL, ALBERTO ZAZZARO. 2014. The Home Bias and the Credit Crunch: A Regional Perspective. Journal of Money, Credit and Banking 46:s1, 53-85. [Crossref]

260. STEVEN ONGENA. 2014. Discussion of Presbitero, Udell, and Zazzaro. Journal of Money, Credit and Banking 46:s1, 87-91. [Crossref]

261. Alexander Popov. 2014. Credit constraints and investment in human capital: Training evidence from transition economies. Journal of Financial Intermediation 23:1, 76-100. [Crossref] 
262. Rajkamal Iyer, José-Luis Peydró, Samuel da-Rocha-Lopes, Antoinette Schoar. 2014. Interbank Liquidity Crunch and the Firm Credit Crunch: Evidence from the 2007-2009 Crisis. Review of Financial Studies 27:1, 347-372. [Crossref]

263. Claire Labonne, Gildas Lame. 2014. Credit Growth and Bank Capital Requirements: Binding or Not?. SSRN Electronic Journal . [Crossref]

264. Milton Harris, Christian C. Opp, Marcus M. Opp. 2014. Macroprudential Bank Capital Regulation in a Competitive Financial System. SSRN Electronic Journal . [Crossref]

265. Marco Di Maggio, Amir Kermani, Rodney Ramcharan. 2014. Monetary Policy Pass-Through: Household Consumption and Voluntary Deleveraging. SSRN Electronic Journal . [Crossref]

266. Monika Bucher, Achim Hauck, Ulrike Neyer. 2014. Frictions in the Interbank Market and Uncertain Liquidity Needs: Implications for Monetary Policy Implementation. SSRN Electronic Journal . [Crossref]

267. Tobias Adrian, Nellie Liang. 2014. Monetary Policy, Financial Conditions, and Financial Stability. SSRN Electronic Journal . [Crossref]

268. Diana Bonfim, Carla Soares. 2014. The Risk-Taking Channel of Monetary Policy Exploring All Avenues. SSRN Electronic Journal . [Crossref]

269. Annalisa Ferrando, Klaas Mulier. 2014. Discouraged Borrowers in the Euro Area. SSRN Electronic Journal . [Crossref]

270. Rustom M. Irani, Ralf R. Meisenzahl. 2014. Loan Sales and Bank Liquidity Risk Management: Evidence from a U.S. Credit Register. SSRN Electronic Journal . [Crossref]

271. Ugo Albertazzi, Margherita Bottero, Gabriele Sene. 2014. Sharing Information on Lending Decisions: An Empirical Assessment. SSRN Electronic Journal . [Crossref]

272. Puriya Abbassi, Falk Brruning, Falko Fecht, Jose-Luis Peydro. 2014. Cross-Border Liquidity, Relationships and Monetary Policy: Evidence from the Euro Area Interbank Crisis. SSRN Electronic Journal . [Crossref]

273. Bahar $\tilde{A}-z t \tilde{A} 1 / 4 r k$, Mico Mrkaic. 2014. SMEsâ€ $€^{\mathrm{TM}}$ Access to Finance in the Euro Area: What Helps or Hampers?. IMF Working Papers 14:78, 1. [Crossref]

274. Ricardo Reis. 2013. Central Bank Design. Journal of Economic Perspectives 27:4, 17-44. [Abstract] [View PDF article] [PDF with links]

275. Tor Jacobson, Jesper Lindé, Kasper Roszbach. 2013. FIRM DEFAULT AND AGGREGATE FLUCTUATIONS. Journal of the European Economic Association 11:4, 945-972. [Crossref]

276. Emilia Garcia-Appendini, Judit Montoriol-Garriga. 2013. Firms as liquidity providers: Evidence from the 2007-2008 financial crisis. Journal of Financial Economics 109:1, 272-291. [Crossref]

277. Roberto A. De Santis, Paolo Surico. 2013. Bank lending and monetary transmission in the euro area. Economic Policy 28:75, 423-457. [Crossref]

278. Matteo Ciccarelli, Angela Maddaloni, José-Luis Peydró. 2013. Heterogeneous transmission mechanism: monetary policy and financial fragility in the eurozone. Economic Policy 28:75, 459-512. [Crossref]

279. SEBNEM KALEMLI-OZCAN, ELIAS PAPAIOANNOU, JOSÉ-LUIS PEYDRÓ. 2013. Financial Regulation, Financial Globalization, and the Synchronization of Economic Activity. The Journal of Finance 68:3, 1179-1228. [Crossref]

280. Ignazio Angeloni, Ester Faia. 2013. Capital regulation and monetary policy with fragile banks. Journal of Monetary Economics 60:3, 311-324. [Crossref] 
281. Ana I. Fernández, Francisco González, Nuria Suárez. 2013. How do bank competition, regulation, and institutions shape the real effect of banking crises? International evidence. Journal of International Money and Finance 33, 19-40. [Crossref]

282. Timothy Besley, Neil Meads, Paolo Surico. 2013. Risk Heterogeneity and Credit Supply: Evidence from the Mortgage Market. NBER Macroeconomics Annual 27:1, 375-419. [Crossref]

283. José-Luis Peydró. 2013. Comment. NBER Macroeconomics Annual 27:1, 420-428. [Crossref]

284. Francois Koulischer, Daan Struyven. 2013. Central Bank Liquidity Provision and Collateral Quality. SSRN Electronic Journal . [Crossref]

285. Tumer Kapan, Camelia Minoiu. 2013. Balance Sheet Strength and Bank Lending During the Global Financial Crisis. SSRN Electronic Journal . [Crossref]

286. Tobias Adrian, Daniel M. Covitz, Nellie Liang. 2013. Financial Stability Monitoring. SSRN Electronic Journal . [Crossref]

287. Rajkamal Iyer, Samuel Da-Rocha Lopes, Jose-Luis Peydro, Antoinette Schoar. 2013. Interbank Liquidity Crunch and the Firm Credit Crunch: Evidence from the 2007-2009 Crisis. SSRN Electronic Journal . [Crossref]

288. Alexander A. Popov, Neeltje van Horen. 2013. The Impact of Sovereign Debt Exposure on Bank Lending: Evidence from the European Debt Crisis. SSRN Electronic Journal . [Crossref]

289. Steven Ongena, Jose-Luis Peydro, Neeltje van Horen. 2013. Shocks Abroad, Pain at Home? BankFirm Level Evidence on the International Transmission of Financial Shocks. SSRN Electronic Journal . [Crossref]

290. Claire Labonne, Gildas Lame. 2013. Credit Growth and Bank Capital Requirements in the French Banking Sector. SSRN Electronic Journal . [Crossref]

291. Vikram Jambulapati, Joanna Stavins. 2013. The Credit CARD Act of 2009: What Did Banks Do?. SSRN Electronic Journal . [Crossref]

292. Giacomo Carboni, Matthieu Darracq Paries, Christoffer Kok Sorensen. 2013. Exploring the Nexus between Macro-Prudential Policies and Monetary Policy Measures: Evidence from an Estimated DSGE Model for the Euro Area. SSRN Electronic Journal . [Crossref]

293. Christoffer Kok Sorensen, Glenn Schepens. 2013. Bank Reactions after Capital Shortfalls. SSRN Electronic Journal . [Crossref]

294. Pierluigi Balduzzi, Emanuele Brancati, Fabio Schiantarelli. 2013. Financial Markets, Banks' Cost of Funding, and Firms' Decisions: Lessons from Two Crises. SSRN Electronic Journal . [Crossref]

295. Paolo Del Giovane, Andrea Nobili, Federico Maria Signoretti. 2013. Supply Tightening or Lack of Demand? An Analysis of Credit Developments During the Lehman Brothers and the Sovereign Debt Crises. SSRN Electronic Journal . [Crossref]

296. Fabian Valencia. 2013. Aggregate Uncertainty and the Supply of Credit. IMF Working Papers 13:241, 1. [Crossref]

297. IMF. Monetary and Capital Markets Department. Global Financial Stablity Report, October 2013: Transition Challenges to Stability . [Crossref]

298. Tümer Kapan, Camelia Minoiu. 2013. Balance Sheet Strength and Bank Lending During the Global Financial Crisis. IMF Working Papers 13:102, 1. [Crossref]

299. Matthew Osborne, Ana-Maria Fuertes, Alistair K. L. Milne. 2012. In Good Times and in Bad: Bank Capital Ratios and Lending Rates. SSRN Electronic Journal . [Crossref]

300. Gabriel Jiménez, Steven R. G. Ongena, Jose-Luis Peydro, Jesus Saurina Salas. 2012. Credit Supply Versus Demand: Bank and Firm Balance-Sheet Channels in Good and Crisis Times. SSRN Electronic Journal . [Crossref] 
301. Huidan Lin, Daniel Paravisini. 2011. What's Bank Reputation Worth? The Effect of Fraud on Financial Contracts and Investment. SSRN Electronic Journal . [Crossref]

302. Angela Maddaloni, Matteo Ciccarelli, Jose-Luis Peydro. 2011. Trusting the Bankers: A New Look at the Credit Channel of Monetary Policy. SSRN Electronic Journal . [Crossref]

303. Karolin Kirschenmann. 2011. Credit Rationing in Small Business Bank Relationships. SSRN Electronic Journal . [Crossref]

304. Daniel Paravisini, Veronica Rappoport, Philipp Schnabl, Daniel Wolfenzon. 2011. Dissecting the Effect of Credit Supply on Trade: Evidence from Matched Credit-Export Data. SSRN Electronic Journal . [Crossref]

305. Jesper Linde, Tor Jacobson. 2011. Firm Default and Aggregate Fluctuations. SSRN Electronic Journal . [Crossref]

306. Gabriel Jiménez, Mian Muhammad Atif, Jose-Luis Peydro, Jesus Saurina Salas. 2011. Local Versus Aggregate Lending Channels: The Effects of Securitization on Corporate Credit Supply. SSRN Electronic Journal . [Crossref]

307. Thorsten Beck. 2011. The Role of Finance in Economic Development: Benefits, Risks, and Politics. SSRN Electronic Journal . [Crossref]

308. Vasso Ioannidou, Steven R. G. Ongena, Jose-Luis Peydro. 2009. Monetary Policy, Risk-Taking and Pricing: Evidence from a Quasi-Natural Experiment. SSRN Electronic Journal . [Crossref]

309. Gabriel Jiménez, Jesus Saurina Salas, Steven R. G. Ongena, Jose-Luis Peydro. 2007. Hazardous Times for Monetary Policy: What Do Twenty-Three Million Bank Loans Say about the Effects of Monetary Policy on Credit Risk-Taking?. SSRN Electronic Journal . [Crossref]

310. Shromona Ganguly. Financing Micro, Small, and Medium Enterprises in Indian Industry 6916-6926. [Crossref] 